\title{
Pineapple Residue Ash Reduces Carbon Dioxide and Nitrous Oxide Emissions in Pineapple Cultivation on Tropical Peat Soils at Saratok, Malaysia
}

\author{
Liza Nuriati Lim Kim Choo ${ }^{1,2, *}$, Osumanu Haruna Ahmed ${ }^{2,3,4}$, Nik Muhamad Nik Majid ${ }^{5}$ and \\ Zakry Fitri Abd Aziz ${ }^{2}$ \\ 1 Soil Science, Water and Fertilizer Research Centre, Malaysian Agricultural Research and Development \\ Institute, MARDI Saratok, P.O. Box 59, Saratok 95407, Sarawak, Malaysia \\ 2 Department of Crop Science, Faculty of Agricultural Science and Forestry, Universiti Putra Malaysia, \\ Bintulu Campus, P.O. Box 396, Bintulu 97008, Sarawak, Malaysia; osumanu@upm.edu.my (O.H.A.); \\ zakryfitri@upm.edu.my (Z.F.A.A.) \\ 3 Institute of Tropical Agriculture and Food Security, Universiti Putra Malaysia, \\ Serdang 43400, Selangor, Malaysia \\ 4 Institut Ekosains Borneo, Bintulu Campus, Universiti Putra Malaysia, P.O. Box 396, \\ Bintulu 97008, Sarawak, Malaysia \\ 5 Department of Forest Management, Faculty of Forestry, Universiti Putra Malaysia, \\ Serdang 43400, Selangor, Malaysia; nikmatmajid.upm@gmail.com \\ * Correspondence: lizalim@mardi.gov.my; Tel.: +6019-857-5084
}

check for

updates

Citation: Choo, L.N.L.K.; Ahmed, O.H.; Majid, N.M.N.; Aziz, Z.F.A. Pineapple Residue Ash Reduces Carbon Dioxide and Nitrous Oxide Emissions in Pineapple Cultivation on Tropical Peat Soils at Saratok, Malaysia. Sustainability 2021, 13, 1014. https://doi.org/10.3390/su13031014

Received: 6 November 2020 Accepted: 28 December 2020 Published: 20 January 2021

Publisher's Note: MDPI stays neutral with regard to jurisdictional clai$\mathrm{ms}$ in published maps and institutional affiliations.

Copyright: (C) 2021 by the authors. Licensee MDPI, Basel, Switzerland. This article is an open access article distributed under the terms and conditions of the Creative Commons Attribution (CC BY) license (https:// creativecommons.org/licenses/by/ $4.0 /)$.

\begin{abstract}
Burning pineapple residues on peat soils before pineapple replanting raises concerns on hazards of peat fires. A study was conducted to determine whether ash produced from pineapple residues could be used to minimize carbon dioxide $\left(\mathrm{CO}_{2}\right)$ and nitrous oxide $\left(\mathrm{N}_{2} \mathrm{O}\right)$ emissions in cultivated tropical peatlands. The effects of pineapple residue ash fertilization on $\mathrm{CO}_{2}$ and $\mathrm{N}_{2} \mathrm{O}$ emissions from a peat soil grown with pineapple were determined using closed chamber method with the following treatments: (i) 25, 50, 70, and 100\% of the suggested rate of pineapple residue ash + NPK fertilizer, (ii) NPK fertilizer, and (iii) peat soil only. Soils treated with pineapple residue ash (25\%) decreased $\mathrm{CO}_{2}$ and $\mathrm{N}_{2} \mathrm{O}$ emissions relative to soils without ash due to adsorption of organic compounds, ammonium, and nitrate ions onto the charged surface of ash through hydrogen bonding. The ability of the ash to maintain higher soil $\mathrm{pH}$ during pineapple growth primarily contributed to low $\mathrm{CO}_{2}$ and $\mathrm{N}_{2} \mathrm{O}$ emissions. Co-application of pineapple residue ash and compound NPK fertilizer also improves soil ammonium and nitrate availability, and fruit quality of pineapples. Compound NPK fertilizers can be amended with pineapple residue ash to minimize $\mathrm{CO}_{2}$ and $\mathrm{N}_{2} \mathrm{O}$ emissions without reducing peat soil and pineapple productivity.
\end{abstract}

Keywords: compound fertilizers; greenhouse gases; histosols; pineapples; plant residues; waste management

\section{Introduction}

In situ burning of pineapple residues on tropical peat soils before replanting of pineapples is a waste management practice in the pineapple industry. For every growing season, about $13 \mathrm{t} /$ ha of pineapple residues are generated [1], but in situ recycling of pineapple residues, especially pineapple leaves during replanting of pineapples, is comparatively low vis a vis the total amount of residues generated from pineapple roots, stems, leaves, crowns, peduncles, and fruits [2]. Open burning of pineapple residues raises concern on the hazards of peat fires, $\mathrm{CO}_{2}$ and $\mathrm{N}_{2} \mathrm{O}$ emissions, and the sustainability of managing pineapple residues, because $90 \%$ of pineapples (Ananas comosus L. Merr) are cultivated on peat soils in Malaysia [3]. Burning pineapple residues on tropical peat soils, particularly during the dry season, leads to air pollution and regional haze in Malaysia, Singapore, 
and Indonesia. Exposure to unhealthy air quality may cause respiratory diseases such as asthma, lung cancer, and death because haze pollutant contains fine particulate matter (diameter less than $2.5 \mu \mathrm{m}$ ) that can penetrate blood streams and lungs [4-6]. However, the adverse health effects largely depend on exposure and spatial proximity to population areas $[4,5]$. Peat fires emit toxic gaseous compounds that are carcinogenic, including furfurals, benzene, and aliphatic and aromatic hydrocarbons [5,7]. Additionally, peat fires may lead to acid rain, loss of biodiversity, and plant photosynthesis reduction [6].

In situ burning of pineapple residues neither improves macronutrient uptake nor pineapple yield, although this practice minimizes the occurrence of pests and diseases $[1,8]$. At present, there is limited information concerning the effects of burned pineapple residues on $\mathrm{CO}_{2}$ and $\mathrm{N}_{2} \mathrm{O}$ emissions from drained peat soils grown with pineapple despite the possibility that ash, the by-product of burned pineapple residues could increase soil $\mathrm{pH}$ and accelerate microbial metabolism for organic matter decomposition $[9,10]$. Unlike the oil palm industry, where extensive studies had been carried out to measure greenhouse gas emissions from oil palm plantations on peat [11-13], less attention has been focused on drained peatlands under pineapples cultivation. Pineapples cultivation on peat soils in Malaysia was reported to release approximately $179.6 \mathrm{t} \mathrm{CO}_{2} \mathrm{ha}^{-1} \mathrm{yr}^{-1}$ [14] and $15.7 \mathrm{t} \mathrm{N}_{2} \mathrm{O} \mathrm{ha}^{-1} \mathrm{yr}^{-1}$ [15]. While efforts had been carried out to quantify $\mathrm{CO}_{2}$ and $\mathrm{N}_{2} \mathrm{O}$ emissions from tropical peat soils cultivated with pineapple [16-19], the effects of pineapple residue ash on $\mathrm{CO}_{2}$ and $\mathrm{N}_{2} \mathrm{O}$ emissions from drained peat soils are yet to be determined in field and laboratory experiments.

Naturally, tropical peat soils are sinks for $\mathrm{CO}_{2}$ and a negligible source of $\mathrm{N}_{2} \mathrm{O}[9,10]$. However, once these organic soils are drained for agriculture as an example, their upper layers become aerobic and oxidizes. This process results in large emissions of $\mathrm{CO}_{2}$ and $\mathrm{N}_{2} \mathrm{O}$ as organic matter decomposes [20,21]. $\mathrm{CO}_{2}$ is emitted from peat soils through microbial respiration, root respiration, physical oxidation, and burning of plant litter and organic matter or by wildfires [22-24]. $\mathrm{N}_{2} \mathrm{O}$ emission is derived from both nitrification and denitrification processes that are regulated by microbial activities $[25,26]$. The emission of $\mathrm{CO}_{2}$ from peat soils is influenced by land use type [27], type of peat [28], temperature [29], photosynthetic activities [30], and fertilization [24,31]. Soil water content, temperature, nitrogen availability, and fertilization affect $\mathrm{N}_{2} \mathrm{O}$ emission from peat soils $[25,26,32,33]$.

According to the conventional agronomic management for pineapples grown on drained peat soils, fertilization is commonly carried out using Bordeaux mixture (foliar fertilization) and compound (NPK 30:1:32) fertilizers [34]. For nitrogen-based fertilizers, their effects on $\mathrm{CO}_{2}$ and $\mathrm{N}_{2} \mathrm{O}$ emissions had been attributed to the association of nitrogen fertilization with factors that directly or indirectly influence soil microbial activities [35]. Application of ammonium-nitrogen fertilizers on peat soils had been reported to reduce $\mathrm{CO}_{2}$ emission because of a reduction in the decomposition of organic matter and an increase in soil acidity [36].

To date, the mechanism that explains how ash affects $\mathrm{CO}_{2}$ and $\mathrm{N}_{2} \mathrm{O}$ emissions from tropical peat soils is still poorly understood and not elucidated. Ash application may increase $\mathrm{CO}_{2}$ emission because of the stimulation of microbial activities [37]. Additionally, ash may co-metabolize soil organic matter in peat soils through increased production of extracellular enzymes [38]. Increase in soil microbial activity and organic matter decomposition resulting in higher $\mathrm{CO}_{2}$ emission can also be related to increase in soil $\mathrm{pH}$ following ash application because of its alkalinity $[9,32,35]$. Although $\mathrm{N}_{2} \mathrm{O}$ emission is commonly related to nitrogen fertilization [39], increase in soil $\mathrm{pH}$ following application of ash can affect microbial nitrification and denitrification processes because higher total nitrogen gas emissions had been reported to occur under neutral soil environment compared with acidic and alkaline conditions [10]. On the contrary, reduction of $\mathrm{CO}_{2}$ and $\mathrm{N}_{2} \mathrm{O}$ emissions following ash application could be attributed to soil organic matter sorption of ash, especially within the pores and external surfaces of the ash, to suppress oxidative organic matter degradation [37,40]. Moreover, calcium ions in ash had been reported to inhibit nitrification and denitrification [10]. However, several studies had reported that 
the mechanism behind the reduction of $\mathrm{CO}_{2}$ and $\mathrm{N}_{2} \mathrm{O}$ emissions indirectly relates to an increase in soil $\mathrm{pH}[9,10,37,40]$.

$\mathrm{CO}_{2}$ and $\mathrm{N}_{2} \mathrm{O}$ emission reported in Malaysia in 2011 from cropland, including drained cultivated peat soils, was $18,316.05 \mathrm{Gg} \mathrm{CO}_{2}$ eq and 10,994.94 $\mathrm{Gg} \mathrm{CO}_{2}$ eq of $\mathrm{N}_{2} \mathrm{O}$ [41]. The annual loss of these greenhouse gases is expected to increase because of large-scale or production agriculture [42,43]. Thus, the understanding of the co-application of pineapple residue ash and compound NPK fertilizers to minimize greenhouse gases from tropical peat soils grown with pineapple is essential. Plant residue ash differs from that of biochar. Generally, plant residue ash is the final inorganic non-combustible fraction after complete thermochemical combustion [44-46]. The non-combustible fraction primarily contains the mineral components of the original plant residue. In comparison, biochar is a solid carbonaceous by-product of organic materials produced through a thermochemical process under limited oxygen called pyrolysis [47-50]. Both plant residue ash and biochar have various uses, such as reducing soil acidification due to their alkaline nature, soil amendment in improving the fertility of degraded soils, and fertilizer materials for agricultural and horticultural purposes $[46,49,51]$. However, their potential application and physicochemical characteristics depend on the type of biomass, combustion or pyrolysis conditions (temperature), and residence time [52-54].

Since the 1960s, the Malaysian pineapple industry has contributed to, and it continues to significantly improve, Malaysia's gross domestic product and financial and economic progress [55]. In 2018, Malaysia's total pineapple production was 375,900 metric tons [56], while its export production value is forecasted to increase approximately $51.6 \%$ or by US\$ 80.4 million in 2020 [57]. This projection further indicates that the importance of the pineapple industry to the country's socio-economic growth, notably the well-being of pineapple farmers, cannot be ignored or disregarded. Therefore, an alternative approach is needed to sustainably manage pineapple wastes not only to minimize environmental pollution but also to improve nutrient use efficiency for pineapple grown on peat soils and the economy of pineapple-producing countries. Converting pineapple wastes into value-added products such as potassium-humate for application in fertigation systems [58], such as a fiber substitution in the paper production industry [59] and biowaste compost to improve soil fertility [60], are some alternative means of managing pineapple residues sustainably. Pineapple residues are also used as raw materials to extract cellulose nanoparticles for application in the pharmaceutical, automotive, and biomedical industries [61]. Generally, plant residues are converted into activated carbons to remove heavy metals in water treatment plants, air filters, and decolorization and deodorization purposes in the food industry [62].

Based on the aforementioned rationale, the objective of this study was to determine the effects of pineapple residue ash on $\mathrm{CO}_{2}$ and $\mathrm{N}_{2} \mathrm{O}$ emissions from a drained tropical peat soils grown with pineapple. In this study, we postulated that pineapple residue ash will decrease peat soil $\mathrm{CO}_{2}$ and $\mathrm{N}_{2} \mathrm{O}$ emissions. This hypothesis is based on the assumption that the functional groups in pineapple residue ash will enable adsorption of anionic organic compounds and ammonium ions onto the charged surface of the ash, thereby protecting organic matter and nutrients from microbial degradation. To test this hypothesis, the closed chamber method was used to measure $\mathrm{CO}_{2}$ and $\mathrm{N}_{2} \mathrm{O}$ emissions on peat soils cultivated with pineapple on drained sapric peat soil, which is fertilized with compound NPK fertilizers and pineapple residue ash. A laboratory incubation experiment was conducted to verify the findings obtained in the field study. It is hoped that the present study could present a deeper understanding on the mechanism of $\mathrm{CO}_{2}$ and $\mathrm{N}_{2} \mathrm{O}$ emissions affected by fertilization as well as providing information on crop residue management besides the potential mitigation measures to reduce $\mathrm{CO}_{2}$ and $\mathrm{N}_{2} \mathrm{O}$ emissions from drained tropical peat soils grown with pineapples. 


\section{Materials and Methods}

\subsection{Experimental Site Description}

A field study was carried out from December 2016 to March 2018 at the Peat Research Station located within the vicinity of the Malaysian Agricultural Research and Development Institute (MARDI) in Saratok, Malaysia at the following coordinates: $1^{\circ} 55^{\prime} 30.9^{\prime \prime} \mathrm{N}$ $111^{\circ} 14^{\prime} 15.1^{\prime \prime} \mathrm{E}$. The soil is classified as sapric peat soil, is dark brown, and has a strong smell with thickness ranging from 0.5 to $3 \mathrm{~m}$. According to the Von Post Scale, the peat soil falls under group $\mathrm{H7}$ to $\mathrm{H} 9$, which is highly decomposed with faintly recognized plant materials. The total peatland area at the research station encompassed 387 hectares and was heavily logged for high value timbers species from 1970 to 1990 . The monthly rainfall distribution pattern exhibits a dry period in July $(172 \mathrm{~mm})$ and an intense wet period between November and January $(450$ to $514 \mathrm{~mm})$. The experimental site has a mean annual rainfall of $3923 \mathrm{~mm}$, whereas the mean annual temperature is $27.7^{\circ} \mathrm{C}$. The mean temperature at the research station ranges from 22.8 to $32.5^{\circ} \mathrm{C}$, while mean relative humidity ranges from 55.2 to $60.1 \%$ throughout the year. Meteorological data presented were calculated based on a 19-year average (from 2000 to 2018) obtained from an existing weather station installed at the research site.

\subsection{Peat Soil Physical and Chemical Characteristics}

Prior to establishing the field study in 2016, the experimental site (one hectare) was cultivated with pineapple (Moris cultivar) and Zingiber officinale Roscoe. (Bentong ginger variety) from 2012 to 2015, after which it was abandoned to fallow for one and a half years. The felling-burying technique was employed to remove trees, shrubs, woody biomass, old crop stands, and vegetation from the experimental area in December 2016. This land clearing technique involves felling, stacking, and burying plant debris (at a depth of $2 \mathrm{~m}$ ) in dug-out pits using a hydraulic excavator. Water table depth varies between 29 to $38 \mathrm{~cm}$ at the experimental site. Physical and chemical properties of the peat soils were determined, namely bulk density, water holding capacity, moisture, $\mathrm{pH}$, electrical conductivity, cation exchange capacity (CEC), total organic carbon, total nitrogen, exchangeable ammonium, and available nitrate. For this purpose, soil samples at depths of 0 to $20 \mathrm{~cm}, 20$ to $40 \mathrm{~cm}$, and 40 to $60 \mathrm{~cm}$ were taken systematically at 16 points over a $20 \mathrm{~m} \times 20 \mathrm{~m}$ grid. The core method was used to determine the soil bulk density [63], whereas the gravimetric method was utilized to analyze the soil moisture [63]. Soil $\mathrm{pH}$ and electrical conductivity were measured in a ratio of 1:5 soil to water suspension [64]. Soil CEC was measured using the Harada and Inoko method [65]. Total organic carbon was determined using the method of Walkley and Black [66]. The Kjeldahl method was used to determine total nitrogen [67], whereas the steam distillation method was utilized to measure exchangeable ammonium-nitrogen and available nitrate [68].

\subsection{Preparation and Characterization of Pineapple Residue Ash}

Pineapple residues, namely stems, crowns, peduncles, and leaves, were obtained from small-scale pineapple growers at Saratok, Malaysia. Pineapple residue ash was prepared by manually removing impurities using water, after which the residues were air-dried, shredded, and oven-dried at $80^{\circ} \mathrm{C}$ for three days. Afterward, the oven-dried residues were incinerated using a muffle furnace (Carbolite ELF11/6) for one hour at $300{ }^{\circ} \mathrm{C}$, after which samples were calcined at $600{ }^{\circ} \mathrm{C}$ for $10 \mathrm{~min}$. The color of the pineapple residue ash was nearly white. In this present study, the emission of gaseous compounds from the combustion of pineapple residues in the muffle furnace chamber was not identified nor quantified. Ash was produced under controlled conditions using a laboratory furnace.

The $\mathrm{pH}$ of the pineapple residue ash was determined based on a 1:10 ash to water suspension [69]. The CEC of the pineapple residue ash was measured according to the method by Wiersum and Bakema [70]. Fourier Transform Infrared (FTIR) (Nicolet 6700, Thermo Electron Corporation, Madison, WI, USA) was used to identify functional groups in pineapple residue ash, whereas an Ultra High Resolution Scanning Electron Microscope 
(FESEM) with Energy Dispersive X-Ray (EDX) (Nova NanoSem 230, Fei Company, Hillsboro, OR, USA) was used to determine their elemental and morphological characteristics. A surface area analyzer was used to determine the surface area of pineapple residue ash (ASAP 2460, Micromeritics Instrument Corp, Norcross, GA, USA).

\subsection{Field Experimental Design and Treatments}

The field study was a $6 \times 4 \times 5$ factorial experiment in a randomized complete block design (RCBD) with three replications involving (i) six rates of fertilizer treatments (a mixture of pineapple residue ash and compound NPK fertilizer): T1 to T6; (ii) four gas flux measurements: 1, 7, 15, and 30 days after fertilization; and (iii) five sampling time: morning, noon, evening, midnight, and morning - following day. Pineapples were planted on raised beds measuring $1 \mathrm{~m}$ (width) $\times 3.5 \mathrm{~m}$ (length) $\times 0.4 \mathrm{~m}$ (height). A total of 18 raised beds were built in December 2016, and the distance between each raised bed was $0.5 \mathrm{~m}$. The Moris cultivar was used as the test crop because it is one of the most cultivated varieties in Sarawak, Malaysia. Suckers were used as propagation material in this study. The Moris suckers were planted at a planting distance of $30 \mathrm{~cm} \times 60 \mathrm{~cm}$ in two rows on each raised bed. For each raised bed, there were a total of 18 pineapple plants. The pineapples were planted on raised beds to minimize flooding, particularly during the wet monsoon season. The pineapple plants were managed using standard agronomic procedures for pineapple grown on tropical peat soils [34].

The field experiment involves six treatments comprising different amounts of pineapple residue ash (Table 1). The recommended rate of pineapple residue ash applied was calculated according to the compound NPK fertilizer requirement for pineapples grown on peat soils [34]. The recommended rate of pineapple residue ash applied refers to the nutrient requirement of pineapple at the vegetative and fruiting stages [34,71]. The compound $\mathrm{N}_{2} \mathrm{O}: \mathrm{P}_{2} \mathrm{O}_{5}: \mathrm{K}_{2} \mathrm{O}$ fertilizer used in this present study has a ratio of 30:1:32. The compound NPK fertilizer contained ammonium sulfate, Christmas Island rock phosphate, and muriate potash. For each treatment (T1 to T5), the amount of compound NPK fertilizer used was 20 g. Fertilization was carried out at three, six, and nine months after planting in March, June, and September 2017, respectively. Pineapple residue ash and compound NPK fertilizers were meticulously mixed according to the aforementioned treatments and application rates (Table 1). The mixture was applied circularly onto the peat soil, approximately $5 \mathrm{~cm}$ from the base of the pineapple plants. Treatment T1 containing $20 \mathrm{~g}$ of pineapple residue ash $(100 \%)$ was selected as a treatment to determine the effect of the amount of ash on the leaching and adsorption of macronutrients and greenhouse gas emissions in peat soils. It was hypothesized that a higher amount of ash would increase the number of negatively charged surfaces for nutrient and organic adsorption or ion exchange. Soil samples were obtained at depths of 0-30 cm, 30-60 cm, and 60-90 cm every 7, 15, and 30 days after fertilization, after which they were analyzed for $\mathrm{pH}$, exchangeable ammonium, and available nitrate according to the method by Ismail et al. [64] and Bremner and Keeney [68], respectively. The soil samples were taken at the aerobic $(0$ to $30 \mathrm{~cm})$ and anaerobic $(30$ to $60 \mathrm{~cm}$ and 60 to $90 \mathrm{~cm}$ ) zones for the determination of leached ammonium, nitrate, phosphorus, and potassium using the ion exchange method [72,73] that was not reported in this present study. Pineapple fruit was harvested in February 2018 (14 months after planting), after which the total soluble solids (TTS) of the fruits were measured using a refractometer (Atago PAL-1, Spectrum Technologies Inc., Aurora, IL, USA). 
Table 1. Pineapple residue ash and compound NPK fertilizer application rates for pineapple grown on a drained tropical peat soil.

\begin{tabular}{ccc}
\hline & Fertilization Treatments & Application Rate (per Plant) \\
\hline T1 & $100 \%$ PA + compound NPK fertilizer & 20.0 g of PA + 20 g of NPK fertilizer 30:1:32 \\
\hline T2 & $70 \%$ PA + compound NPK fertilizer & $14.0 \mathrm{~g}$ of PA + 20 g of NPK fertilizer 30:1:32 \\
\hline T3 & $50 \%$ PA + compound NPK fertilizer & $10.0 \mathrm{~g}$ of PA + 20 g of NPK fertilizer 30:1:32 \\
\hline T4 & $25 \%$ PA + compound NPK fertilizer & $5.0 \mathrm{~g}$ of PA + 20 g of NPK fertilizer 30:1:32 \\
\hline T5 & Control: Compound NPK fertilizer only & 20 g of NPK fertilizer 30:1:32 \\
\hline T6 & Control: Peat soil alone (without fertilizer) & Nil \\
\hline
\end{tabular}

Note: PA—pineapple residue ash; compound NPK fertilizer ratio—30:1:32.

\subsection{Gas Flux Measurements}

The closed chamber method [74] was used to trap soil $\mathrm{CO}_{2}$ and $\mathrm{N}_{2} \mathrm{O}$ emitted from the soil surface in the field experiments. Eighteen closed chambers were constructed using acrylic material measuring $20 \mathrm{~cm}$ (width) $\times 20 \mathrm{~cm}$ (length) $\times 20 \mathrm{~cm}$ (height). The closed chambers were square-shaped but have a hollow base with sharp edges. Battery-operated fans were installed in each closed chamber to enable equilibrium gas pressure within and outside the chamber during sampling. The acrylic closed chambers were attached to a square acrylic collar that was pushed vertically approximately $6 \mathrm{~cm}$ into the soil. This depth was chosen because peat decomposition takes place in the upper $10 \mathrm{~cm}$ of the peat profile and soil temperature decreases rapidly with increasing depth [25]. The top of the collar was sealed with a self-adhesive foam gasket to prevent gas leaks. The closed chambers were placed between rows of pineapple plants. Upon attaining equilibrium (30 min), gas samples of $20 \mathrm{~mL}$ were extracted from the chamber using a polypropylene syringe equipped with a three-way stopcock, after which the extracted gas was transferred into a $20 \mathrm{~mL}$ glass vial. The gas samples were analyzed for $\mathrm{CO}_{2}$ and $\mathrm{N}_{2} \mathrm{O}$ simultaneously using gas chromatography (Agilent 7890A, Agilent Technologies Inc, Wilmington, DE, USA) fitted with thermal conductivity (TCD), flame ionization (FID), and micro-electron capture (ECD) detectors with stainless steel packed columns. The operating temperatures of the TCD, FID, and micro-ECD were 200,250 , and $350{ }^{\circ} \mathrm{C}$, respectively, whereas the flow rate was $20 \mathrm{~mL} \mathrm{~min}^{-1}$.

The gas flux was calculated based on the increase in gas concentration within the chamber with time, chamber volume, and soil area covered by the chamber according to Equation (1) [74,75]:

$$
\text { Flux }=[d(\mathrm{Gas}) d t] \times P V / A R T
$$

In which (i) $d(\mathrm{Gas} / d t)$ represents the evolution rate of $\mathrm{CO}_{2}$ or $\mathrm{N}_{2} \mathrm{O}$ within the chamber headspace at a specified time after depositing the chamber in place; (ii) $P$ represents the atmospheric pressure; (iii) $V$ represents the volume of headspace in the chamber; (iv) $A$ represents the area of soil covered by the chamber; (v) $R$ represents the gas constant; and (vi) $T$ represents the air temperature. The flux value was determined from the slope of the linear regression of gas concentration versus time. The values were converted into units of $\mathrm{kg} \mathrm{ha}^{-1} \mathrm{yr}^{-1}$.

The gas flux was measured in the morning (6 a.m.), noon (12 p.m.), evening (6 p.m.), midnight (12 a.m.), and in the morning of the following day (6 a.m.) to acquire a 24-hour greenhouse gas emission. Measurements of $\mathrm{CO}_{2}$ and $\mathrm{N}_{2} \mathrm{O}$ flux were carried out every $1,7,15$, and 30 days after pineapple residue ash and compound NPK fertilization for pineapple in March, June, and September 2017. Soil temperature was measured using Eijkelkamp IP68 sensors (Eijkelkamp, Giesbeek, The Netherlands) at the same time of the flux measurement, whereas climatic data (temperature, air humidity, and rainfall) were recorded using a weather station installed at the study site (WatchDog 2900ET, Spectrum Technologies Inc, Plainfield, IL, USA). 


\subsection{Laboratory Experiment}

A laboratory incubation experiment with peat soils $[36,76]$ was conducted to determine the effects of pineapple residue ash on $\mathrm{CO}_{2}$ and $\mathrm{N}_{2} \mathrm{O}$ emissions. The same treatments evaluated in the field study (Table 1) were also used in the laboratory experiment. Rates of the pineapple residue ash and compound NPK fertilizers applied were scaled down from the standard fertilizer recommendation for pineapple cultivation (ratio of 1:5 ash to fertilizer). The experiment was carried out in a controlled condition $\left(26^{\circ} \mathrm{C}\right)$ arranged in completely randomized design (CRD) with three replications.

Peat soil samples used in the laboratory study were collected from the field experimental site located within the vicinity of the research station. Soil samples at a depth of 0 to $10 \mathrm{~cm}$ were obtained systematically at 16 points over a $20 \mathrm{~m} \times 20 \mathrm{~m}$ grid, which were then bulked. For each treatment, $120 \mathrm{~g}$ of soil was placed in a one-liter conical flask. The peat soils were aerobically pre-incubated for four days at room temperature $\left(26^{\circ} \mathrm{C}\right)$ in a dark chamber to stimulate microbial activity and also to prevent evaporative water loss [36,76]. At the start of the experiment (Day 0), pineapple residue ash and compound NPK fertilizers were added to each flask and manually mixed thoroughly based on the aforementioned treatments (Table 1). The flasks were sealed with a silicone rubber stopper equipped with a thermometer and septa for gas sampling. The treatments were incubated at room temperature $\left(26^{\circ} \mathrm{C}\right)$ for 30 days at approximately $80 \%$ soil moisture content. Sub-soil samples were collected at day 7, 15, and 30 of incubation, after which they were analyzed for $\mathrm{pH}$ [64], exchangeable ammonium, and available nitrate [68].

The $\mathrm{CO}_{2}$ and $\mathrm{N}_{2} \mathrm{O}$ production rates were measured daily for a period of 30 days. Gas samples were extracted using a polypropylene syringe equipped with a three-way stopcock before closure of the flask and at the end of four-hour period [36]. Extracted gas samples were transferred into $20 \mathrm{~mL}$ vacuum vials and analyzed for $\mathrm{CO}_{2}$ and $\mathrm{N}_{2} \mathrm{O}$ using gas chromatography (Agilent 7890A, Agilent Technologies Inc, Wilmington, DE, USA) fitted with TCD, FID, and micro-ECD detectors. The gas flux was calculated as the difference between the two sampling occasions (before and after closure of the flask). Results obtained were expressed in $\mu \mathrm{g} \mathrm{g}^{-1}$ soil $^{-1}$.

\subsection{Statistical Analysis}

Analysis of variance (ANOVA) was utilized to evaluate treatment effects, whereas significant differences between treatment means were compared using Tukey's New Multiple Range Test with $p \leq 0.05$. The linear mixed effects model utilizing the mixed (Proc MIXED) procedure with repeated measures analysis was performed to test the significance of fertilizer rate as the fixed effect and flux measurement and sampling time as random effects on soil $\mathrm{CO}_{2}$ and $\mathrm{N}_{2} \mathrm{O}$ emissions. Data subjected to linear mixed effects model test were not significant for the random effects, and thus, the general linear model (Proc GLM) procedure was used. Pearson correlation analysis was performed to assess the relationship between $\mathrm{CO}_{2}, \mathrm{~N}_{2} \mathrm{O}$, and soil temperature. Statistical analyses were carried out using the Statistical Analysis System (SAS) Version 9.1.

\section{Results}

\subsection{Peat Soil Physicochemical Properties}

The physical and chemical characteristics of the peat soils at the experimental site before commencing the study are presented in Table 2. Results of the soil properties were compared to those reported for tropical peat soils in Southeast Asia [76-85]. There was no significant difference between soil physical properties (bulk density) and depth except for soil moisture. Soil bulk density, $\mathrm{pH}$, electrical conductivity, CEC, and total organic carbon were similar regardless of soil depth, and these results are within the reported range [77-80,82-85]. Total nitrogen, exchangeable ammonium, and available nitrate of the peat soil were high, and these nutrients showed significant differences with increasing soil depths. The total nitrogen was within the reported range [83-85], whereas ammonium and nitrate values are higher than the reported range [76]. 
Table 2. Selected physicochemical properties of a drained sapric peat soil at different soil depths at the Malaysian Agricultural Research and Development Institute (MARDI) Peat Research Station, Saratok, Malaysia.

\begin{tabular}{|c|c|c|c|c|}
\hline \multirow{2}{*}{ Variable } & \multicolumn{3}{|c|}{ Value Obtained per Soil Depth $(\mathrm{cm})$} & \multirow{2}{*}{ Reported Range } \\
\hline & 0 to $20 \mathrm{~cm}$ & 20 to $40 \mathrm{~cm}$ & 40 to $60 \mathrm{~cm}$ & \\
\hline $\begin{array}{l}\text { Bulk density } \\
\qquad\left(\mathrm{g} \mathrm{cm}^{-3}\right)\end{array}$ & $0.14^{\mathrm{a}} \pm 0.003$ & $0.13^{\mathrm{a}} \pm 0.002$ & $0.13^{\mathrm{a}} \pm 0.002$ & $\begin{array}{l}0.1 \text { to } 0.2[80] \\
0.12-0.20[81] \\
0.09-0.16[84]\end{array}$ \\
\hline Moisture (\%) & $81.2^{\mathrm{c}} \pm 0.5$ & $85.6^{\mathrm{b}} \pm 0.4$ & $89.3^{\mathrm{a}} \pm 0.3$ & $\begin{array}{l}90-95[83] \\
75.45[76]\end{array}$ \\
\hline $\mathrm{pH}$ & $3.9^{a} \pm 0.1$ & $3.9^{\mathrm{a}} \pm 0.1$ & $3.9^{\mathrm{a}} \pm 0.1$ & $\begin{array}{c}3.0-4.5[80] \\
3.59-3.90[78]\end{array}$ \\
\hline $\begin{array}{l}\text { Electrical conductivity } \\
\qquad\left(\mu \mathrm{S} \mathrm{cm}^{-1}\right)\end{array}$ & $177.4^{\mathrm{a}} \pm 2.3$ & $176.1^{\mathrm{a}} \pm 1.5$ & $173.2^{\mathrm{a}} \pm 1.7$ & $\begin{array}{l}159.8-358[78] \\
\quad<200[82]\end{array}$ \\
\hline $\begin{array}{l}\text { Cation exchange } \\
\text { capacity } \\
\left(\mathrm{cmol}_{(+)} \mathrm{kg}^{-1}\right)\end{array}$ & $143.2^{\mathrm{a}} \pm 11.1$ & $135.5^{\mathrm{a}} \pm 10.2$ & $139.5^{\mathrm{a}} \pm 14.4$ & $\begin{array}{c}200[77] \\
161.1[79] \\
145[82]\end{array}$ \\
\hline $\begin{array}{l}\text { Total organic } \\
\text { carbon }(\%)\end{array}$ & $41.8^{\mathrm{a}} \pm 0.5$ & $41.1^{\mathrm{a}} \pm 0.3$ & $40.7^{a} \pm 0.4$ & $\begin{array}{c}12-60[77] \\
24.86[84] \\
62.2[85]\end{array}$ \\
\hline Total nitrogen (\%) & $1.39^{a} \pm 0.02$ & $1.13^{\mathrm{b}} \pm 0.01$ & $1.11^{\mathrm{b}} \pm 0.02$ & $\begin{array}{c}1.10-1.67[83] \\
1.21-2.98[84] \\
1.34[85]\end{array}$ \\
\hline $\begin{array}{l}\text { Ammonium-nitrogen } \\
\left(\mathrm{mg} \mathrm{kg}^{-1}\right)\end{array}$ & $1098.3^{a} \pm 15.6$ & $1081.4^{\mathrm{a}} \pm 14.7$ & $738.2^{b} \pm 11.3$ & $642.1[76]$ \\
\hline $\begin{array}{l}\text { Nitrate-nitrogen } \\
\left(\mathrm{mg} \mathrm{kg}^{-1}\right)\end{array}$ & $549.1^{a} \pm 9.8$ & $445.3^{b} \pm 10.6$ & $322.9^{\mathrm{c}} \pm 14.1$ & $174.42[76]$ \\
\hline
\end{tabular}

Means (value \pm standard error) with different letters across the column indicate significant differences using Tukey's test with $p \leq 0.05(\mathrm{n}=48)$.

\subsection{Characteristics of Pineapple Residue ash}

Selected physicochemical properties of pineapple residue ash are presented in Table 3. The pineapple residue ash is alkaline with a $\mathrm{pH}$ value of 12.34 , whereas it is low in CEC. The major and minor elements in the pineapple residue ash were oxygen, magnesium, calcium, phosphorus, and potassium, whereas the functional groups identified were hydroxyl $(\mathrm{O}-\mathrm{H})$ stretching vibration, carbon-oxygen $(\mathrm{C}-\mathrm{O})$ radicals, and methylene $\left(\mathrm{CH}_{2}\right)$. The pineapple residue ash has a high total surface area, whereas FESEM micrographs, as shown in Figure 1, indicate that pineapple residue ash is amorphous.

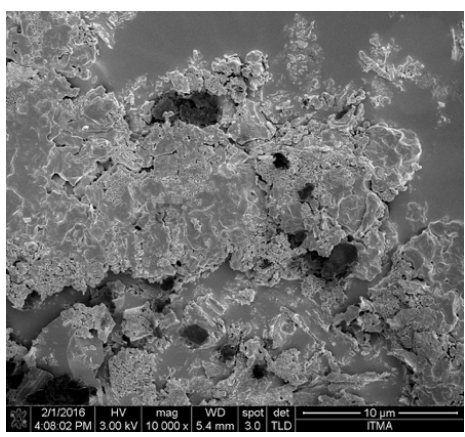

(a)

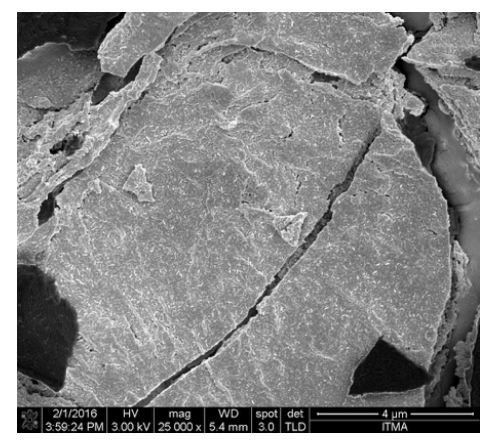

(b)

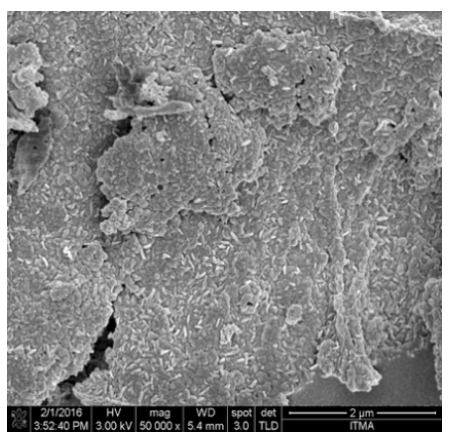

(c)

Figure 1. Ultra High Resolution Scanning Electron Microscope (FESEM) micrographs of pineapple residue ash at different optical magnifications: (a) $10 \mu \mathrm{m}$ (b) $4 \mu \mathrm{m}$ and (c) $2 \mu \mathrm{m}$. 
Table 3. Selected physicochemical characteristics of pineapple residue ash.

\begin{tabular}{cc}
\hline Properties & Values \\
\hline $\mathrm{pH}$ & $12.34( \pm 0.02)$ \\
\hline Cation exchange capacity $\left(\mathrm{cmol}_{+} \mathrm{kg}^{-1}\right)$ & $23.0( \pm 0.15)$ \\
\hline & $\mathrm{O}_{2}: 67.5$ \\
Chemical composition (weight $\%)$ & $\mathrm{Mg}: 20.6$ \\
& $\mathrm{Ca}: 6.8$ \\
& $\mathrm{P}: 4.0$ \\
Functional groups $\left(\mathrm{cm}^{-1}\right)$ & $\mathrm{OH}: 3696.17$ \\
\hline Surface area $\left(\mathrm{m}^{2} \mathrm{~g}^{-1}\right)$ & $\mathrm{CH}: 1415.87$ \\
\hline Values in parenthesis represent the standard error of the mean. & 365.2 \\
\hline
\end{tabular}

Values in parenthesis represent the standard error of the mean.

\subsection{Soil $\mathrm{CO}_{2}$ from Peat Soils Grown with Pineapples}

Pineapple residue ash application significantly affected $\mathrm{CO}_{2}$ emission, but the emission differed according to the amount of ash applied and vegetative phase of the pineapple plants (Figure 2a). With the exclusion of T3 and T1, peat soils treated with pineapple residue ash significantly reduced $\mathrm{CO}_{2}$ emission compared with those without ash (T5 and T6) throughout the growth period of the pineapple plants. During the early development of the pineapple plants (three months age), the $\mathrm{CO}_{2}$ emission from $\mathrm{T} 3$ was higher compared with other treatments, including the controls ( $\mathrm{T} 5$ and $\mathrm{T} 6$ ). However, at six months after planting the pineapple suckers, T3 and T1 showed lower $\mathrm{CO}_{2}$ emission than with NPK fertilization without ash (T5), but the emission from T3 was significantly higher compared with non-treated peat soils (T6). During flower induction (nine months old), the $\mathrm{CO}_{2}$ emissions in the control treatments (T5 and $\mathrm{T} 6$ ) remained higher compared with those with ash (T1 to T4).

Throughout the pineapple growth and development, the average $\mathrm{CO}_{2}$ emissions (Figure 2c) were significantly lower in treatments T1, T2, and T4 compared with the controls, but T4 was most effective in decreasing the $\mathrm{CO}_{2}$ emission. Additionally, $\mathrm{T} 4$ was most effective in retaining exchangeable ammonium and nitrate relative to other treatments (T1 to T3), including NPK fertilization without ash (T5: control) (Table 4). During the pineapple growth phases, peat soils treated with pineapple residue ash (T1 to T4) also showed higher soil pH (Table 4) and total soluble solids (fruit quality) (Table 5) than with the control treatments (T5 and T6). The treatments with pineapple residue ash (T1 to T3) significantly increased fresh fruit weight compared with the controls except T4 (Table 5). Averaged soil $\mathrm{CO}_{2}$ emissions were significantly higher at three months after planting. Thereafter, the $\mathrm{CO}_{2}$ emissions decreased (Figure 3). 


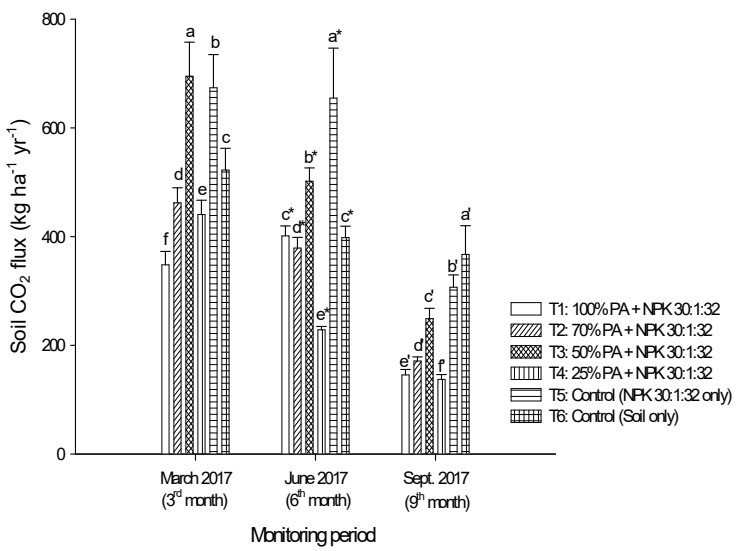

(a)

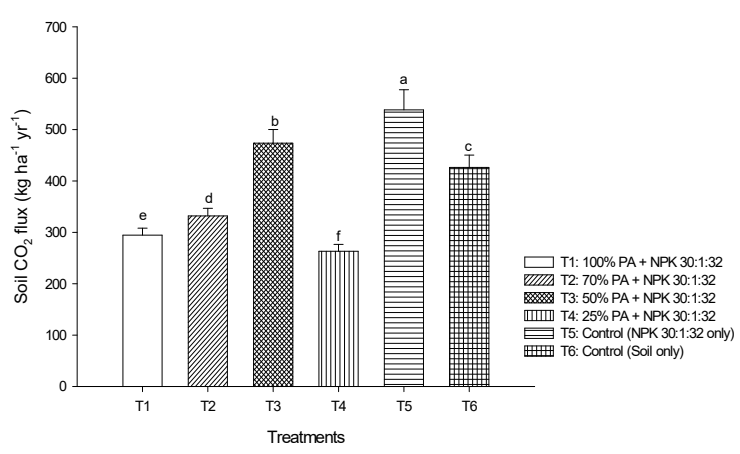

(c)

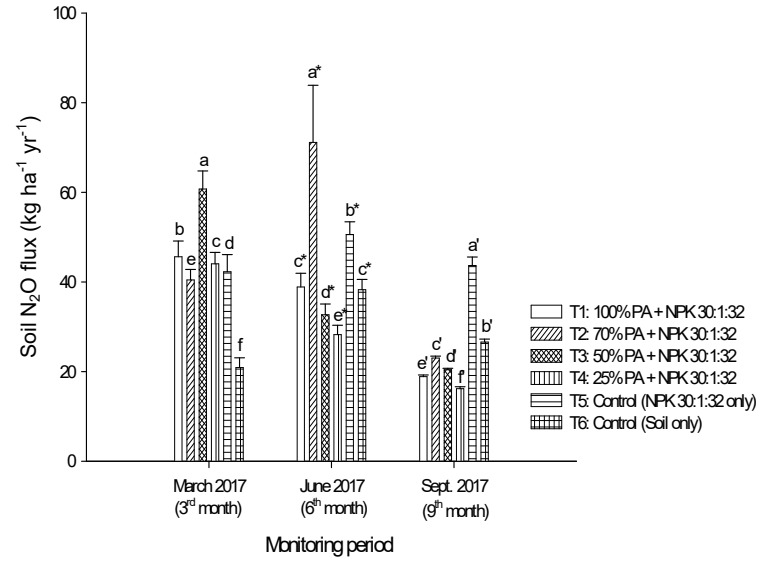

(b)

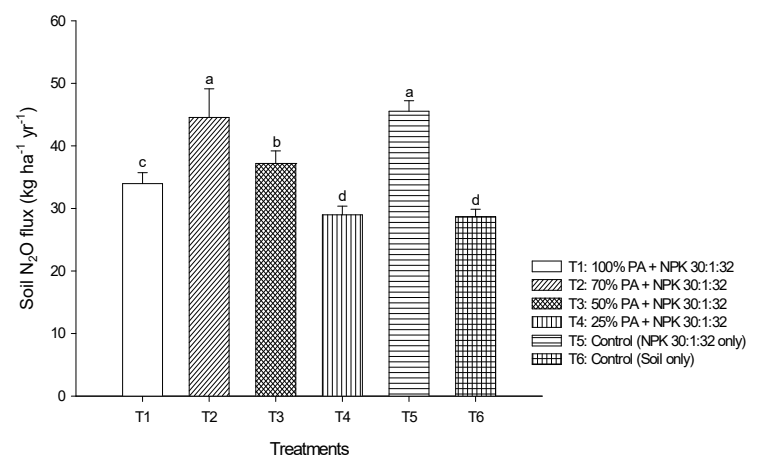

(d)

Figure 2. Soil (a) $\mathrm{CO}_{2}$ and (b) $\mathrm{N}_{2} \mathrm{O}$ emissions from peat soils with pineapple residue ash and compound NPK fertilization at different vegetative stages, and averaged (c) $\mathrm{CO}_{2}$ and (d) $\mathrm{N}_{2} \mathrm{O}$ emissions from treatments throughout the pineapple growing season. Error bars indicate the standard error of the mean $(n=1080)$. Means with different letters are significantly different using Tukey's test with $p \leq 0.05$. PA: pineapple residue ash. Letters with an asterisk represent sixth-month pineapple age, and prime represents ninth-month pineapple age.

Table 4. Mean $\mathrm{pH}$, exchangeable ammonium, and available nitrate in a drained peat soil (at all soil depths: at 0-30 cm, $30-60 \mathrm{~cm}$, and 60-90 cm) grown with pineapples treated with different amounts of pineapple residue ash and compound NPK fertilizer.

\begin{tabular}{|c|c|c|c|c|c|}
\hline \multirow{2}{*}{ Treatments } & \multicolumn{3}{|c|}{ Pineapple Plant Age (Soil pH) } & \multirow{2}{*}{$\begin{array}{l}\text { Exchangeable Ammonium } \\
\qquad\left(\mathrm{mg} \mathrm{kg}^{-1}\right)\end{array}$} & \multirow{2}{*}{$\begin{array}{l}\text { Available Nitrate } \\
\quad\left(\mathrm{mg} \mathrm{kg}^{-1}\right)\end{array}$} \\
\hline & 3 Months & 6 Months & 9 Months & & \\
\hline $\mathrm{T} 1$ & $5.84^{b} \pm 0.06$ & $5.99^{b} \pm 0.06$ & $6.31^{\mathrm{c}} \pm 0.03$ & $688.76^{d} \pm 5.67$ & $279.68^{\mathrm{c}} \pm 2.44$ \\
\hline $\mathrm{T} 2$ & $6.13^{\mathrm{a}} \pm 0.07$ & $6.18^{a} \pm 0.05$ & $6.36^{b} \pm 0.07$ & $553.42 \mathrm{e} \pm 4.39$ & $231.85^{\mathrm{e}} \pm 3.06$ \\
\hline T3 & $5.87^{\mathrm{b}} \pm 0.12$ & $6.02^{b} \pm 0.08$ & $6.43^{\mathrm{a}} \pm 0.05$ & $1438.68^{b} \pm 10.37$ & $246.62^{\mathrm{d}} \pm 4.27$ \\
\hline $\mathrm{T} 4$ & $5.66^{c} \pm 0.09$ & $5.96^{\mathrm{c}} \pm 0.02$ & $6.05^{\mathrm{d}} \pm 0.07$ & $1465.52^{\mathrm{a}} \pm 8.05$ & $577.13^{\mathrm{a}} \pm 2.85$ \\
\hline $\mathrm{T} 5$ & $4.40^{\mathrm{d}} \pm 0.03$ & $4.22^{\mathrm{d}} \pm 0.02$ & $4.19^{\mathrm{e}} \pm 0.02$ & $704.25^{c} \pm 3.76$ & $324.93^{b} \pm 7.46$ \\
\hline T6 & $3.92^{\mathrm{e}} \pm 0.07$ & $4.14^{\mathrm{e}} \pm 0.02$ & $4.05^{\mathrm{f}} \pm 0.01$ & $1460.40^{\mathrm{a}} \pm 7.15$ & $237.61^{\mathrm{e}} \pm 5.74$ \\
\hline
\end{tabular}

Values (mean \pm standard error) with different letters within the same column are significantly different using Tukey's test with $p \leq 0.05$ $(n=486)$. 
Table 5. Total soluble solids and fresh fruit yield of Ananas comosus L. Merr grown on a tropical peat soil treated with different amounts of pineapple residue ash and compound NPK fertilizer.

\begin{tabular}{ccc}
\hline Treatments & Total Soluble Solids $\left({ }^{\circ}\right.$ Brix) & Fresh Fruit Weight $(\mathbf{k g})$ \\
\hline T1 & $13.62^{\mathrm{a}} \pm 0.02$ & $2.10^{\mathrm{a}} \pm 0.05$ \\
T2 & $13.48^{\mathrm{ab}} \pm 0.06$ & $2.00^{\mathrm{ab}} \pm 0.003$ \\
T3 & $13.51^{\mathrm{ab}} \pm 0.03$ & $1.92^{\mathrm{b}} \pm 0.02$ \\
T4 & $13.29^{\mathrm{b}} \pm 0.05$ & $1.80^{\mathrm{c}} \pm 0.01$ \\
T5 & $12.82^{\mathrm{c}} \pm 0.05$ & $1.72^{\mathrm{cd}} \pm 0.04$ \\
T6 & $12.65^{\mathrm{c}} \pm 0.09$ & $1.61^{\mathrm{d}} \pm 0.01$ \\
\hline
\end{tabular}

$\overline{\text { Means (value } \pm \text { standard error) with different letters within the same column indicate significant differences }}$ using Tukey's test with $p \leq 0.05(\mathrm{n}=324)$.

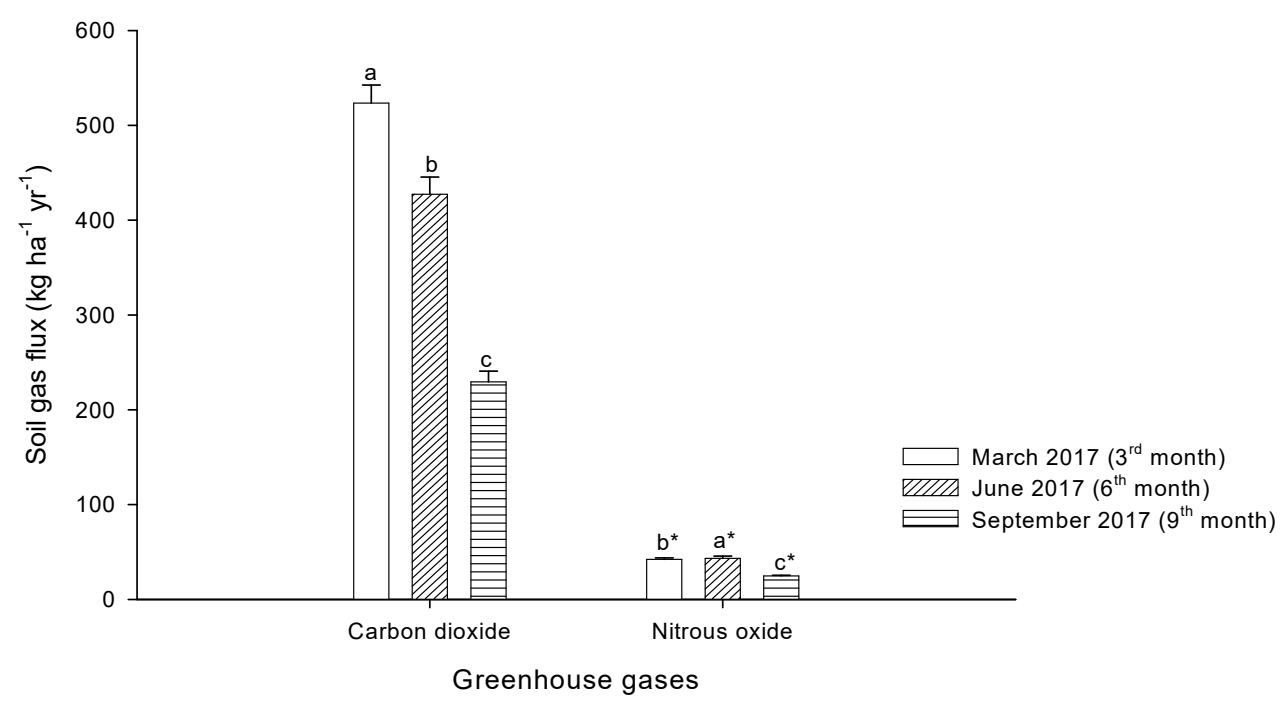

Figure 3. Averaged $\mathrm{CO}_{2}$ and $\mathrm{N}_{2} \mathrm{O}$ emissions over all treatments ( $\mathrm{T} 1$ to $\mathrm{T} 6$ ) from tropical peat soils throughout the pineapple growing season in 2017 ( $\mathrm{n}=2160)$. Error bars indicate the standard error of the mean. Means with different letters are significantly different using Tukey's test with $p \leq 0.05$. Letters with an asterisk represent $\mathrm{N}_{2} \mathrm{O}$ emissions.

During the growth period of the pineapple plants, there was no distinct $\mathrm{CO}_{2}$ emission pattern of fertilization (Figure $4 a, c$ ) nor a distinct pattern of time of gas sampling (Figure $5 \mathrm{a}, \mathrm{c}$ ). With the exception of the flower induction phase (nine months age), $\mathrm{CO}_{2}$ emission was higher at day 1 after fertilization but lower at day 30 throughout the pineapple growth period (three and six months old) (Figure 4a). Likewise, the averaged $\mathrm{CO}_{2}$ emission (over all treatments: T1 to T6) was higher at day 1 after fertilization but lower at day 30 (Figure 4c).

Compared with the time of sampling (Figure 5a), at three and six months after planting, the $\mathrm{CO}_{2}$ emission was higher in the morning but decreased at noon, followed by an increase in the evening to midnight, after which the emission decreased until the following morning. Conversely, $\mathrm{CO}_{2}$ emission was higher at noon but lower in the morning (following day) at the flower induction phase. The averaged $\mathrm{CO}_{2}$ emission from peat soils was higher in the morning but decreased from noon to evening, followed by an increase at midnight, after which the $\mathrm{CO}_{2}$ emission decreased until the following morning (Figure $5 \mathrm{c}$ ).

Throughout the pineapple growth period, there was no significant correlation between $\mathrm{CO}_{2}$ emission and soil temperature (Table 6). However, the mean soil temperature was significantly different depending on the time of gas sampling, whereas the mean dayand night-time temperature differences were low throughout the vegetative phase of the pineapple plants (March to September 2017) (Table 6). 


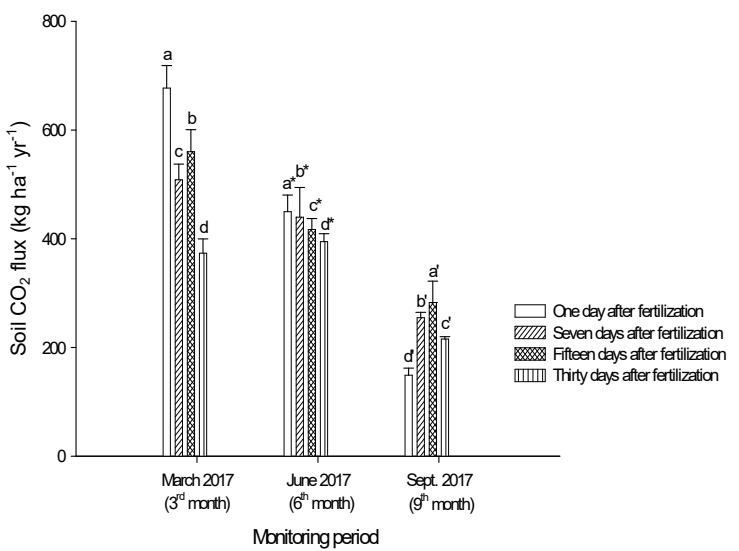

(a)

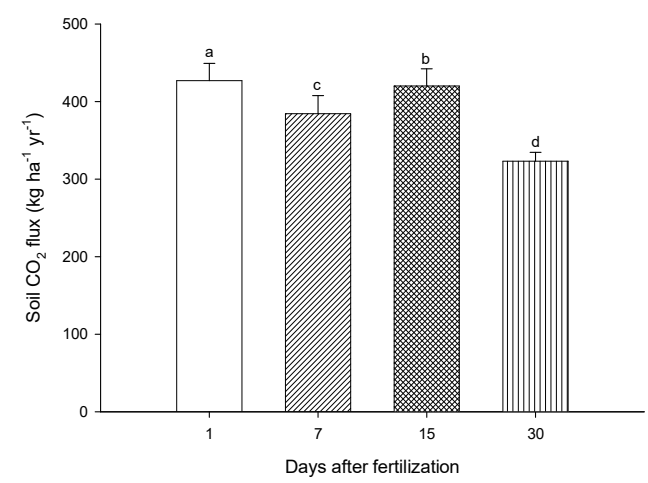

(c)

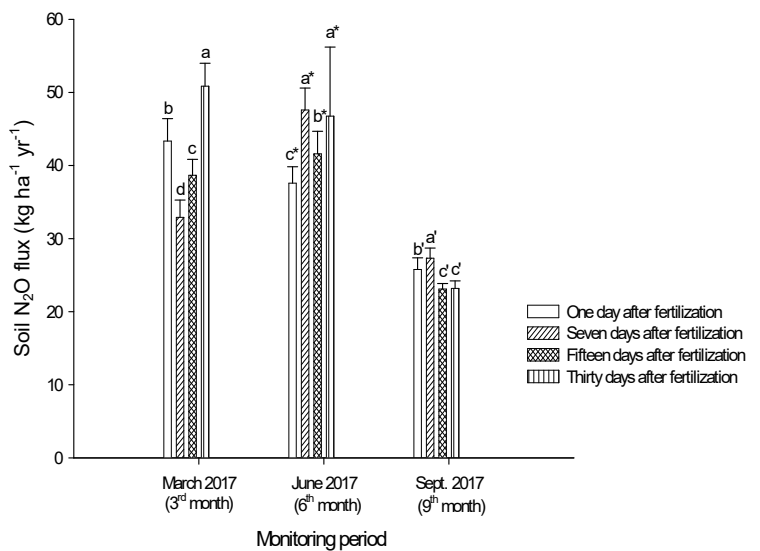

(b)

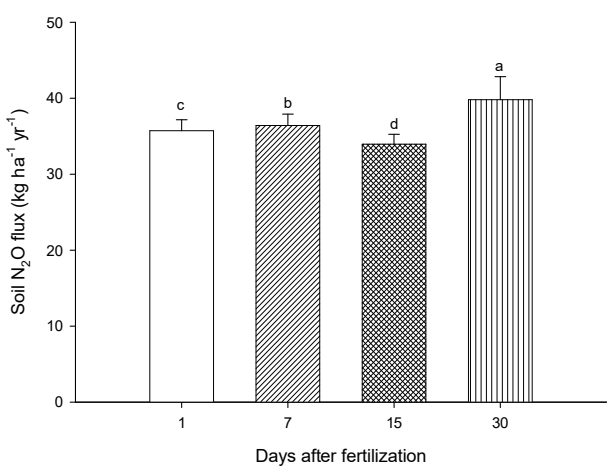

(d)

Figure 4. Soil (a) $\mathrm{CO}_{2}$ and (b) $\mathrm{N}_{2} \mathrm{O}$ emissions after fertilization from peat soils grown with pineapple at different vegetative stage, and the averaged (c) $\mathrm{CO}_{2}$ and (d) $\mathrm{N}_{2} \mathrm{O}$ emissions after fertilization over all treatments (T1 to T6) throughout the pineapple growing season. Error bars indicate the standard error of the mean $(n=1080)$. Means with different letters are significantly different using Tukey's test with $p \leq 0.05$. Letters with an asterisk represent sixth-month pineapple age, and prime represents ninth-month pineapple age.

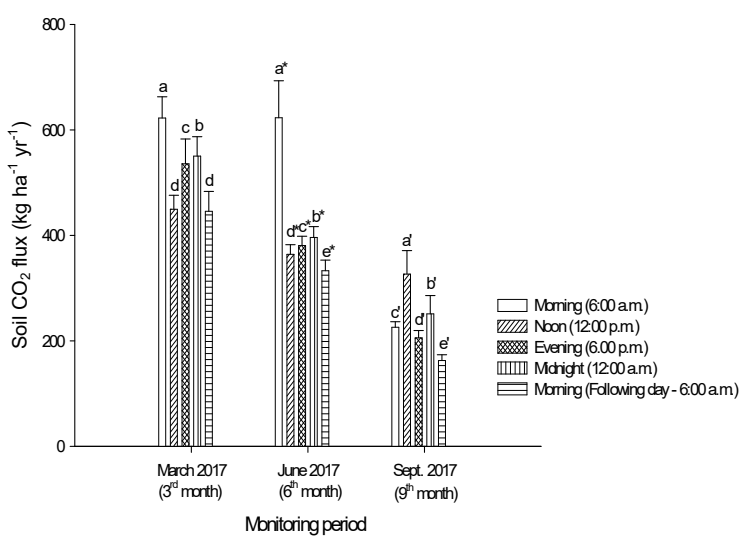

(a)

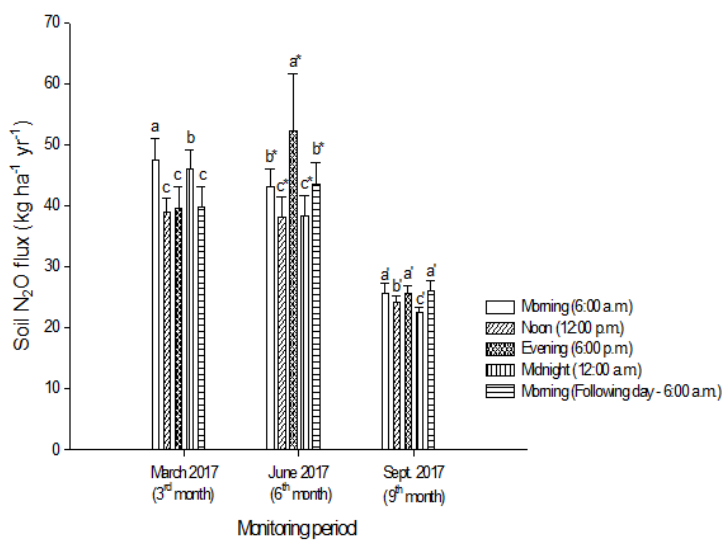

(b)

Figure 5. Cont. 


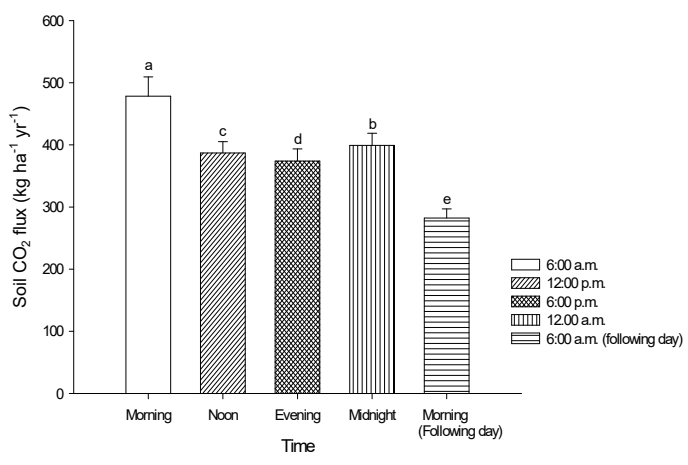

(c)

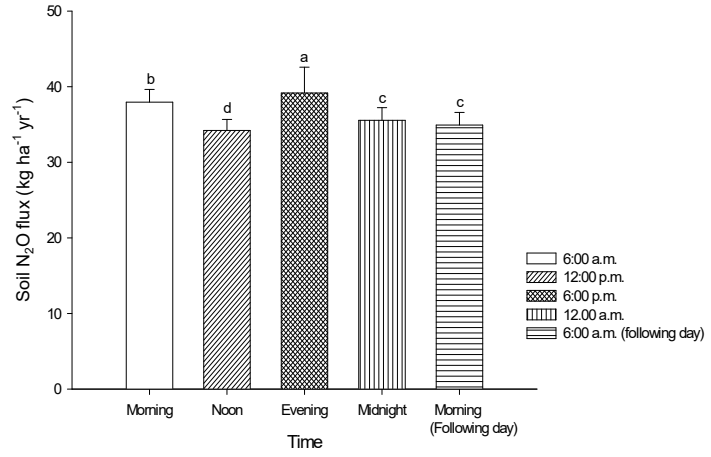

(d)

Figure 5. Soil (a) $\mathrm{CO}_{2}$ and (b) $\mathrm{N}_{2} \mathrm{O}$ emissions at different times of the day from peat soils grown with pineapple at different vegetative stage, and averaged (c) $\mathrm{CO}_{2}$ and (d) $\mathrm{N}_{2} \mathrm{O}$ emissions at different times over all treatments (T1 to T6) throughout the pineapple growing season. Error bars indicate the standard error of the mean $(n=1080)$. Means with different letters are significantly different using Tukey's test with $p \leq 0.05$. Letters with an asterisk represent sixth-month pineapple age, and prime represents ninth-month pineapple age.

Table 6. Relationship between soil $\mathrm{CO}_{2}$ and $\mathrm{N}_{2} \mathrm{O}$ emissions, and soil temperature throughout the pineapple growth period, and mean temperatures at the experimental site (MARDI Peat Research Station, Saratok, Malaysia).

\begin{tabular}{|c|c|c|c|}
\hline \multirow[b]{2}{*}{ Variable } & \multicolumn{3}{|c|}{ Pineapple Growth Period (Soil Temperature) } \\
\hline & $\begin{array}{c}\text { March } 2017 \\
\text { (3 Months Old) }\end{array}$ & $\begin{array}{c}\text { June } 2017 \\
\text { (6 Months Old) }\end{array}$ & $\begin{array}{l}\text { September } 2017 \\
\text { (9 Months Old) }\end{array}$ \\
\hline Soil $\mathrm{CO}_{2}$ emission & $\begin{array}{c}r=0.07204 \\
p=0.2089\end{array}$ & $\begin{array}{c}\mathrm{r}=-0.09884 \\
p=0.0756\end{array}$ & $\begin{array}{c}r=0.04833 \\
p=0.3729\end{array}$ \\
\hline \multirow[t]{2}{*}{ Soil $\mathrm{N}_{2} \mathrm{O}$ emission } & $\begin{array}{c}\mathrm{r}=-0.21878 \\
p=0.0001\end{array}$ & $\begin{array}{c}r=0.00602 \\
p=0.9140\end{array}$ & $\begin{array}{c}\mathrm{r}=-0.08808 \\
p=0.1039\end{array}$ \\
\hline & \multicolumn{3}{|c|}{ Soil temperature $\left({ }^{\circ} \mathrm{C}\right)$} \\
\hline Morning & $26.6^{\mathrm{d}}$ & $27.5^{b}$ & $25.9^{\mathrm{d}}$ \\
\hline Noon & $29.1^{b}$ & $29.9^{\mathrm{a}}$ & $29.6^{\mathrm{a}}$ \\
\hline Evening & $30.4^{\mathrm{a}}$ & $30.3^{\mathrm{a}}$ & $29.6^{\mathrm{a}}$ \\
\hline Midnight & $27.7^{\mathrm{c}}$ & $27.7^{\mathrm{b}}$ & $27.2^{b}$ \\
\hline \multirow[t]{2}{*}{ Morning-following day } & $26.1^{\mathrm{d}}$ & $26.7^{\mathrm{c}}$ & $26.5^{c}$ \\
\hline & \multicolumn{3}{|c|}{ Temperature $\left({ }^{\circ} \mathrm{C}\right)$} \\
\hline Mean day-time temperature & 29.2 & 29.5 & 28.7 \\
\hline Mean night-time temperature & 24.3 & 25.0 & 24.4 \\
\hline $\begin{array}{l}\text { Mean day- and night-time } \\
\text { temperature differences }\end{array}$ & 4.9 & 4.5 & 4.3 \\
\hline
\end{tabular}

The top values indicate Pearson's correlation coefficient (r), while the bottom values (P) denote the probability level at $0.05(\mathrm{n}=1080)$. Means (value \pm standard error) with different letters within the same column indicate significant differences using Tukey's test with $p \leq 0.05$.

\subsection{Soil $\mathrm{N}_{2} \mathrm{O}$ from Peat Soils Grown with Pineapples}

During the growth phases of the pineapple plants (Figure 2b), $\mathrm{N}_{2} \mathrm{O}$ emissions from the peat soils only (T6) were lower compared with NPK fertilization (T5). During the early development of the pineapple plants, that is, at three months after planting (March 2017), $\mathrm{N}_{2} \mathrm{O}$ emissions of the pineapple residue ash treatments were significantly higher compared with NPK fertilization (T5), except T2. Conversely, compared with control (T5), the rest of the pineapple residue ash treatments showed lower $\mathrm{N}_{2} \mathrm{O}$ emissions (sixth month after planting), except T2. At the flower induction phase of the pineapple plants (September 
2017), the pineapple residue ash treatments (T1 to T4) effectively decreased $\mathrm{N}_{2} \mathrm{O}$ emission compared with those with no ash (T5 and T6).

With the exception of $\mathrm{T} 2$ (Figure $2 \mathrm{~d}$ ), the averaged $\mathrm{N}_{2} \mathrm{O}$ emissions were significantly lower with the pineapple residue ash treatments (T1, T3, and T4) compared with NPK fertilization (T5). Additionally, T4 was the most effective treatment in decreasing $\mathrm{N}_{2} \mathrm{O}$ emission. This finding on the effectiveness of $\mathrm{T} 4$ is similar to that of $\mathrm{CO}_{2}$ emissions (Figure 2c). The averaged soil $\mathrm{N}_{2} \mathrm{O}$ emissions were significantly higher at six months after planting but lower during the flower induction phase (ninth months after planting) (Figure 3).

Throughout the pineapple growth and development, there was no distinct $\mathrm{N}_{2} \mathrm{O}$ emission pattern with fertilization (Figure $4 b, d$ ) and so was time of gas sampling (Figure 5b,d). During the early development of the pineapple plants (three months old), $\mathrm{N}_{2} \mathrm{O}$ emission was higher at day 30 after fertilization but lower at day 7 (Figure $4 \mathrm{~b}$ ). At six months after planting, $\mathrm{N}_{2} \mathrm{O}$ emission was higher at days 7 and 30 after fertilization but lower at day 1 . However, during the flower induction phase (nine months old), $\mathrm{N}_{2} \mathrm{O}$ emission was higher at day 7 after fertilization but lower at days 15 and 30. Averaged $\mathrm{N}_{2} \mathrm{O}$ emissions (over all treatments: T1 to T6) was higher at day 30 after fertilization but lower at day 15 (Figure 4d).

Compared with time of sampling (Figure 5b), at three months after planting, $\mathrm{N}_{2} \mathrm{O}$ emission was higher in the morning but lower at noon, evening, and the following morning. At six months old, $\mathrm{N}_{2} \mathrm{O}$ emission decreased from morning to noon but peaked in the evening, after which emission decreased at midnight, followed by an increase the following morning. During the flower induction phase, $\mathrm{N}_{2} \mathrm{O}$ emission was higher in the morning, evening, and the following morning, but lower at midnight. Averaged $\mathrm{N}_{2} \mathrm{O}$ emission from peat soils decreased from morning to noon but peaked in the evening, after which the emission decreased until the following morning (Figure $5 \mathrm{~d}$ ).

During the growth period of the pineapple plants, there was no significant correlation between the $\mathrm{N}_{2} \mathrm{O}$ emission and soil temperature (Table 6). However, an exception to this finding was the weak and negative correlation between $\mathrm{N}_{2} \mathrm{O}$ emission and soil temperature at the third month after planting, suggesting that $\mathrm{N}_{2} \mathrm{O}$ emission decreased with increasing temperature.

\subsection{Soil $\mathrm{CO}_{2}$ and $\mathrm{N}_{2} \mathrm{O}$ Emissions from Laboratory Incubation Experiment}

In the laboratory incubation experiment, averaged soil $\mathrm{CO}_{2}$ emissions under the pineapple residue ash treatments (T1 to T3) were lower compared with those without the ash (T5 and T6), except T4 (Figure 6a). Ash-treated peat soils (T3 and T4) showed lower $\mathrm{N}_{2} \mathrm{O}$ emissions compared with other treatments, including controls (Figure 6b). Soil $\mathrm{CO}_{2}$ and $\mathrm{N}_{2} \mathrm{O}$ emissions under NPK fertilization (T5) remained higher, and this occurred throughout the incubation experiment.

Compared with control treatments ( $\mathrm{T} 5$ and $\mathrm{T} 6$ ), the treatments with pineapple residue ash (T1 to T4) showed higher soil $\mathrm{pH}$ (Table 7). Soil exchangeable ammonium and available nitrate varied with treatments (Table 7). The soil exchangeable ammonium was lower in the ash-treated peat soils (T1 to T4) compared with NPK fertilized peat soils (T5). Soil exchangeable ammonium of T6 was lower compared with other treatments. Treatment T1 showed higher available nitrate compared with other treatments, including controls (T5 and $\mathrm{T} 6$ ), but $\mathrm{T} 3$ and $\mathrm{T} 5$ showed lower nitrate contents. 


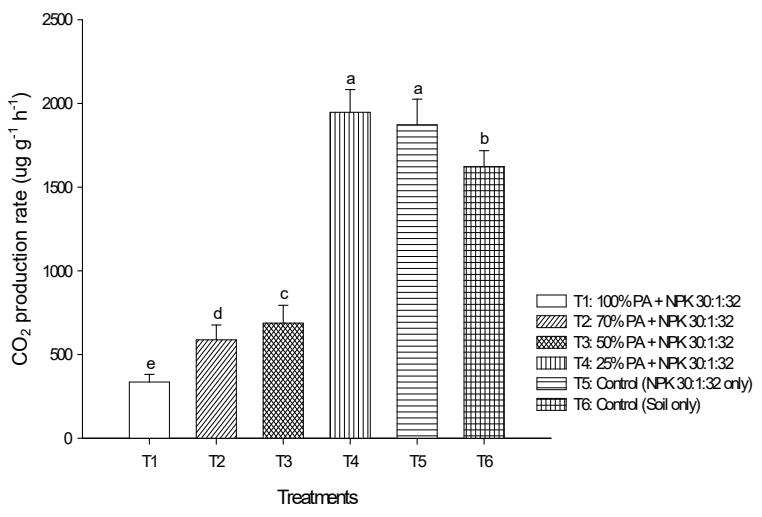

(a)

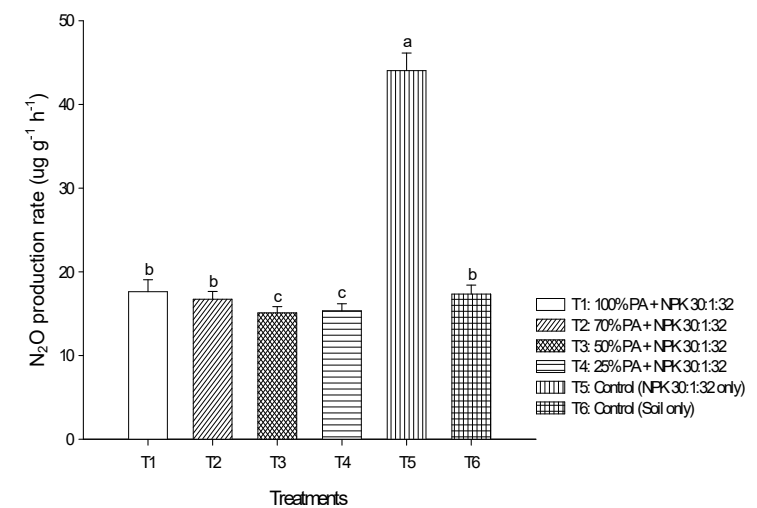

(b)

Figure 6. Averaged soil (a) $\mathrm{CO}_{2}$ and (b) $\mathrm{N}_{2} \mathrm{O}$ emissions from peat soils with pineapple residue ash and compound NPK fertilization after 30 days of incubation in the laboratory. Error bars indicate standard error of the mean $(\mathrm{n}=540)$. Means with different letters are significantly different using Tukey's test with $p \leq 0.05$. PA: pineapple residue ash.

Table 7. Mean soil $\mathrm{pH}$, exchangeable ammonium, and available nitrate after 30 days of incubation in the laboratory treated with different amounts of pineapple residue ash and compound NPK fertilizer.

\begin{tabular}{|c|c|c|c|}
\hline Treatments & $\mathrm{pH}$ & $\begin{array}{l}\text { Exchangeable Ammonium } \\
\qquad\left(\mathrm{mg} \mathrm{kg}^{-1}\right)\end{array}$ & $\begin{array}{l}\text { Available Nitrate } \\
\quad\left(\mathrm{mg} \mathrm{kg}^{-1}\right)\end{array}$ \\
\hline $\mathrm{T} 1$ & $8.18^{a} \pm 0.02$ & $898.01^{\mathrm{d}} \pm 2.19$ & $31.68^{a} \pm 0.22$ \\
\hline $\mathrm{T} 2$ & $8.08^{a} \pm 0.02$ & $1218.61^{b} \pm 3.48$ & $23.70^{\mathrm{c}} \pm 0.92$ \\
\hline T3 & $7.99^{b} \pm 0.01$ & $847.03^{d} \pm 5.27$ & $21.97^{\mathrm{d}} \pm 0.91$ \\
\hline $\mathrm{T} 4$ & $7.49^{b} \pm 0.03$ & $1067.88^{c} \pm 3.62$ & $23.21^{\mathrm{c}} \pm 0.49$ \\
\hline $\mathrm{T} 5$ & $4.71^{\mathrm{c}} \pm 0.02$ & $1318.93^{a} \pm 3.29$ & $21.38^{\mathrm{d}} \pm 0.93$ \\
\hline T6 & $4.10^{c} \pm 0.02$ & $110.49^{\mathrm{e}} \pm 1.97$ & $25.47^{b} \pm 0.71$ \\
\hline
\end{tabular}

Means (value \pm standard error) with different letters within the same column indicate significant differences using Tukey's test with $p \leq 0.05(\mathrm{n}=54)$.

\section{Discussion}

\subsection{Peat Soil Physicochemical Properties}

The water table was high and fluctuated between 29 to $38 \mathrm{~cm}$ throughout the soil sampling activity (before commencing the studies), which was conducted during the wet monsoon season in December 2016. The high water table at the experimental area relatively explains the higher soil moisture content at deeper soil depths. Additionally, the high water table at the study site may have increased the peat pore volume, which somewhat describes the soil's low bulk density. The bulk density of the peat soil in this present study is within the reported range $[80,81,84]$. This observation is related to the oxidative decomposition of organic materials (sapric) once the peatland is drained and cultivated.

The peat soil is acidic but not saline, as indicated by the low soil electrical conductivity. The existing tidal gate located at the primary outlet drain prevents seawater intrusion into the research station. The peat soils' high CEC values relate to ion exchange, particularly exchangeable hydrogen ions from carboxylic and phenolic acids in humic substances and organic colloids [1,77]. The CEC of the peat soil also depends on the nature of its organic matter and decomposition stages [86]. The soil's total organic carbon content is high, which relates to the ligneous woody material in sapric peats. The total nitrogen content is high but is unavailable because nitrogen occurs mostly in organic forms in peat soils [77]. Very little nitrogen is mineralized because of the high $\mathrm{C} / \mathrm{N}$ ratio in peat soils. Thus, this leads to low inorganic nitrogen availability for plant uptake unless a substantial number of nitrogen-based fertilizers are applied. However, the low oxidative decomposition of peat soils with increasing water down the soil profile is associated with 
a decreasing amount of total nitrogen, exchangeable ammonium-nitrogen, and available nitrate-nitrogen with increasing soil depth. The current study was conducted on a drained cultivated peatland, and this somewhat explains the higher contents of exchangeable ammonium-nitrogen and available nitrate-nitrogen of the soil compared to the reported values [76]. Moreover, the inorganic nitrogen values reported [76] were based on the study on a partially drained mixed swamp forest. Furthermore, agronomic practices, fertilization, and planting of ginger and pineapple at the experimental area (2012 to 2015) prior to the study might be partly responsible for the increase in nitrogen mineralization. However, there are no specific reasons that explain the higher ammonium-nitrogen and nitrate-nitrogen to that of total nitrogen at $0-20 \mathrm{~cm}$ and $20-40 \mathrm{~cm}$ soil depths. The anomaly may have been influenced by the delay in the laboratory analysis due to transportation and preparation of the samples before nutrient analysis. The delay may have led to biological transformation, causing changes to the amount and forms of inorganic nitrogen in the sample [68]. Additionally, air-drying of the peat sample may have also led to an increase in ammonium-nitrogen and nitrate-nitrogen. Moreover, clearing of trees, woody biomass, old crop stands, and vegetation (land clearing using the felling-burying technique) at the experimental area in December 2016 may have influenced the decomposition of plant residues and mineralization of soil organic nitrogen.

\subsection{Pineapple Residue Ash Application on $\mathrm{CO}_{2}$ and $\mathrm{N}_{2} \mathrm{O}$ Emissions in Peat Soils Cultivated with Pineapples}

Contrary to the believe that ash increases $\mathrm{CO}_{2}$ and $\mathrm{N}_{2} \mathrm{O}$ emissions, in this present study, it decreased soil $\mathrm{CO}_{2}$ emission because of sorption of organic matter to the ash either onto the external ash surfaces or within the pores of the ash [37]. Sorption of organic matter by the ash inhibited decomposition of organic matter, leading to low $\mathrm{CO}_{2}$ emission. Furthermore, electrostatic repulsion between the negatively charged anionic organic peat compounds and ash might have induced adsorption through hydrogen bonding $[40,87]$. This hydrogen bonding could be associated with the presence of hydroxyl in ash, identified through FTIR analysis (Table 3). The lower $\mathrm{CO}_{2}$ emission with pineapple residue ash can also be attributed to calcium ions in the ash, because it might have influenced the formation of soil mineral aggregates to protect the ash and organic matter in the peat from being rapidly degraded by soil microorganisms $[37,88]$. Moreover, the effectiveness of the pineapple residue ash (T1 to T4) in decreasing $\mathrm{CO}_{2}$ emission at flower induction stage (nine months after planting) was because some of the ash did not rapidly break down over time but it instead remained in the soil to improve nutrient retention [89]. This suggests that sorption of organic matter by ash occurred slowly through diffusion onto the ash surfaces [90].

On the contrary, the higher $\mathrm{CO}_{2}$ emission from the ash treatments, particularly $\mathrm{T} 3$ during the early growth of the pineapple plants, was unexpected. There are no specific reasons that explain the anomaly from the findings obtained. Perhaps the availability of suitable substrate for microbial metabolism and microbial communities of the peat soil may have influenced $\mathrm{CO}_{2}$ emission $[23,28,91]$.

Soil $\mathrm{CO}_{2}$ emission might have also been affected by the degradation of root exudates by rhizosphere microorganisms [23]. Root exudates are labile, easily decomposed, and composed of low molecular weight of organic compounds namely carbohydrates and carboxylic and amino acids [23]. These organic compounds are used as energy sources by microorganisms followed by $\mathrm{CO}_{2}$ release as a by-product of the microbial metabolism. The higher $\mathrm{CO}_{2}$ emission at three months after planting was because of early development of the pineapple rooting system, whereas the lower $\mathrm{CO}_{2}$ emission at nine months after planting relates to the flower induction stage of the pineapple plants where the vegetative growth was less active.

Throughout the pineapple growth period, changes in soil $\mathrm{CO}_{2}$ and $\mathrm{N}_{2} \mathrm{O}$ emission after fertilization across time are difficult to explain. However, the differences in $\mathrm{CO}_{2}$ and $\mathrm{N}_{2} \mathrm{O}$ emissions might have been influenced by the diversity of the microbial structure in the soil. During the early development of the pineapple plants and at six months 
old, the higher $\mathrm{CO}_{2}$ emission at day one after fertilization could be attributed to the readily available nutrients from the fertilizers for microbial degradation, which accelerate peat decomposition. Additionally, soil $\mathrm{CO}_{2}$ emission may have been influenced by the slow release of nutrients with ash treatments, which affected the activity of microbial metabolism leading to lower $\mathrm{CO}_{2}$ emission at day 30 after fertilization. Moreover, $\mathrm{CO}_{2}$ emission might have been affected by the leaching of the nutrients from the fertilizer down the soil profile at the study site, primarily during the beginning of the wet season at nine months after planting (flower induction phase). The $\mathrm{CO}_{2}$ emission might have been affected by heterotrophic activity at the upper surface of the peat, where decomposition mostly takes place $(10 \mathrm{~cm})$ when there are fewer substrates (due to leaching).

Although $\mathrm{CO}_{2}$ emission was affected by the sampling time, the higher $\mathrm{CO}_{2}$ emission at midnight was unexpected, as respiration, which includes root respiration of the pineapple plants, should have dominated during day time but should decrease at night. The cause for this finding is uncertain, but this discrepancy could be associated with pineapple plants. Pineapples are a Crassulacean Acid Metabolism (CAM) plant, which assimilates $\mathrm{CO}_{2}$ at night and keeps them in the form of acid in the leaves while emitting the gas during the day for it to be processed into carbohydrates to increase water efficiency [92,93]. It is able to adsorb $\mathrm{CO}_{2}$ more efficiently with high temperature differences between day and night. However, the low temperature difference between day and night times throughout the pineapple growth cycle in 2017 (Table 6) may have hindered the photosynthetic rate of the plants $[94,95]$. Thus, the CAM plant undergoes less efficient photosynthesis, resembling that of a C3 plant.

The lower $\mathrm{N}_{2} \mathrm{O}$ emission from the unfertilized peat soils compared with NPK fertilization treatments was expected, because in acidic conditions, $\mathrm{N}_{2} \mathrm{O}$ emission from denitrification processes occurs slowly [96]. This observation is consistent with the low soil $\mathrm{pH}$ of the non-fertilized soils, which remained acidic throughout the pineapple growth period (Table 4). Conversely, the higher $\mathrm{N}_{2} \mathrm{O}$ emission in the treatments with NPK fertilization was due to the readily available ammonium and nitrates, which might have influenced the microbially mediated processes of denitrification and nitrification in the rhizosphere [96]. The lower $\mathrm{N}_{2} \mathrm{O}$ emissions in pineapple residue ash-treated peat soils could be primarily attributed to increase in soil $\mathrm{pH}$ because $\mathrm{N}_{2} \mathrm{O}: \mathrm{N}_{2}$ product ratio of denitrification increases with low $\mathrm{pH}[9,10,96]$. During the pineapple growth period, the soil $\mathrm{pH}$ following the application of pineapple residue ash (T1 to T4) was consistently higher (Table 4) compared with controls. Furthermore, adsorption of ammonium ions by hydroxyl onto the charged surface of pineapple residue ash following NPK fertilization may have protected ammonium ions and inhibit microbial nitrification [72,97], leading to low $\mathrm{N}_{2} \mathrm{O}$ emission. The effectiveness of the pineapple residue ash treatments (T1 to T4) in decreasing $\mathrm{N}_{2} \mathrm{O}$ emission at flower induction demonstrates the ability of this material to adsorb organic matter onto its surface through diffusion. Again, these findings suggest that the significant reduction in $\mathrm{N}_{2} \mathrm{O}$ emission was due to accumulation of some of the ash in the peat soils, which did not break down rapidly.

The differences in soil $\mathrm{N}_{2} \mathrm{O}$ emission with time of gas sampling and pineapple growth and development was because $\mathrm{N}_{2} \mathrm{O}$ emission is regulated by nitrification and denitrification. $\mathrm{N}_{2} \mathrm{O}$ emission is influenced by the availability of adequate substrates at the root zone. The substrates were used by nitrifying microorganisms and this led to $\mathrm{N}_{2} \mathrm{O}$ production [96]. Moreover, the diversity and structure of microorganisms at the root zone of the pineapple plants might have influenced $\mathrm{N}_{2} \mathrm{O}$ emission [98]. Similar to that of $\mathrm{CO}_{2}$ emission, changes in $\mathrm{N}_{2} \mathrm{O}$ emissions after fertilization across time throughout the vegetative phases of the pineapple plants might also be affected by the slow release of nutrients with ash treatments and leaching of nutrients from the fertilizers down the soil profile during the wet season.

Soil $\mathrm{CO}_{2}$ and $\mathrm{N}_{2} \mathrm{O}$ emissions were high with NPK fertilization because nitrogenbased fertilizers affect both $\mathrm{CO}_{2}$ and $\mathrm{N}_{2} \mathrm{O}$ emissions by providing nitrogen to plants and microorganisms, and also by influencing soil $\mathrm{pH}$, which also influences microbial activities [32,35]. Although $\mathrm{CO}_{2}$ and $\mathrm{N}_{2} \mathrm{O}$ emissions were affected by time of gas sampling, 
these observations were not consistent with the insignificant correlation between these greenhouse gases and soil temperature (Table 6). This indicates that despite the ability of soil temperature to regulate $\mathrm{CO}_{2}$ and $\mathrm{N}_{2} \mathrm{O}$ emission in peat soils, differences in $\mathrm{CO}_{2}$ and $\mathrm{N}_{2} \mathrm{O}$ emission relatively rely on moderate soil temperature variation in the wet and dry monsoons of Southeast Asia.

Among the pineapple residue ash treatments (T1 to T4), the effectiveness of $\mathrm{T} 4 \mathrm{in}$ decreasing soil $\mathrm{CO}_{2}$ and $\mathrm{N}_{2} \mathrm{O}$ emissions after NPK fertilization (Figure 2c,d) could be associated to the amount of pineapple residue ash used. The lower amount of pineapple residue ash in $\mathrm{T} 4(25 \%)$ concurred with the optimal and equilibrium sorption of organic matter, ammonium, and nitrate onto the charged surface of the ash through hydrogen bonding $[99,100]$ to suppress organic matter degradation. Additionally, this observation is consistent with the higher retention of exchangeable ammonium and available nitrate in ash-treated peats (T4) compared with other treatments (T1 to T3), including control (T5), throughout the pineapple growth period (Table 4). The higher concentration of exchangeable ammonium and available nitrate in $\mathrm{T} 4$ increased nitrogen uptake by pineapple plants, and this explains the higher fruit yield and improved fruit quality (fruit sweetness expressed as total soluble solids in ${ }^{\circ}$ Brix) of the pineapples (Table 5). The temporary adsorption and absorption of ammonium and nitrate ions by pineapple residue ash allow these ions to diffuse when water passes through the soil, causing the ions to be available for plant uptake [72]. The results from this study indicate that utilizing pineapple residues as a soil amendment to minimize $\mathrm{CO}_{2}$ and $\mathrm{N}_{2} \mathrm{O}$ emissions offers an alternative approach for managing pineapple wastes on peat soils without reducing peat soil and pineapple productivity.

Although the types of gaseous compounds emitted during the production of ash using a laboratory furnace were not identified and quantified in this study, it can be assumed that the major gases generated during plant residue combustion are carbon monoxide and carbon dioxide [101]. The emission of these gases during plant residue combustion was because pineapple residues are primarily made up of cellulose, hemicellulose, and lignin [102]. Other gaseous compounds that may be emitted include a minimal amount of hydrogen, methane, and ethane [101].

\subsection{Pineapple Residue Ash on $\mathrm{CO}_{2}$ and $\mathrm{N}_{2} \mathrm{O}$ Emissions in Peat Soils-A Laboratory Incubation Experiment}

In contrast to the in situ field results, in the laboratory experiment, ash-treated peat soil (T4) was not effective in decreasing soil $\mathrm{CO}_{2}$ emission after NPK fertilization compared with the other ash treatments. The reasons for this discrepancy were not clear. However, this anomaly could be ascribed to the availability of adequate substrate, which was microbially utilized, thus leading to higher $\mathrm{CO}_{2}$ emission during the relatively shorter incubation period compared with the field study duration [37]. However, heterogeneity of soil organic matter, water table, and structure of microorganisms at the rhizosphere during the pineapple cultivation might have influenced $\mathrm{CO}_{2}$ emission from the ash-treated peat soils compared to that of the laboratory experiment $[28,103]$. Moreover, the pineapple residue ash was applied thrice (every three months) during the NPK fertilization phase, and this leads to the slow accumulation of ash in the peat soil to enable sorption of organic matter to the ash through diffusion onto ash surface $[89,90]$. This partly explains the effectiveness of all of the ash-treated peat soils (T1 to T4) in decreasing soil $\mathrm{CO}_{2}$ emission in the field experiment compared with the laboratory incubation experiment (T1 to T3).

The effectiveness of the ash in T3 and T4 in decreasing $\mathrm{N}_{2} \mathrm{O}$ emissions after NPK fertilization in the laboratory incubation experiment corroborates the results of the present in situ field gas measurements. Although the exchangeable ammonium and available nitrate contents were low in T3 and T4, in the laboratory incubation experiment, the lower $\mathrm{N}_{2} \mathrm{O}$ emissions from T3 and T4 compared with other treatments including controls could be primarily attributed to increase in soil $\mathrm{pH}$ which ranged from 7.49 to 7.99 (Table 7). It is generally accepted that the $\mathrm{N}_{2} \mathrm{O}: \mathrm{N}_{2}$ product ratio of denitrification decreases with increasing $\mathrm{pH}$. The higher soil $\mathrm{pH}$ in treatments with pineapple residue ash compared with 
NPK fertilized soil including unfertilized peat soils in the laboratory incubation experiment were consistent with the results obtained in the field study. The significant increase in soil $\mathrm{pH}$ under the treatments with ash lends to support the ability of pineapple residue ash to buffer soil $\mathrm{pH}$ in cultivated peat soils to minimize $\mathrm{CO}_{2}$ and $\mathrm{N}_{2} \mathrm{O}$ emissions.

\section{Conclusions}

Application of pineapple residue ash in conjunction with NPK fertilizers decreased $\mathrm{CO}_{2}$ and $\mathrm{N}_{2} \mathrm{O}$ emissions from tropical peat soils cultivated with pineapple. The findings from the study postulated possible mechanisms that could explain the reduction in $\mathrm{CO}_{2}$ and $\mathrm{N}_{2} \mathrm{O}$ emissions with pineapple residue ash application. The effectiveness of pineapple residue ash in decreasing soil $\mathrm{CO}_{2}$ emission is because of the adsorption of anionic organic peat compounds onto the ash through hydrogen bonding to inhibit organic matter degradation. The adsorption of ammonium ions by hydroxyl onto the charged surface of pineapple residue ash following NPK fertilization physically protects ammonium against microbial nitrification, which explains the low $\mathrm{N}_{2} \mathrm{O}$ emission from ash-treated peat soils. The buffering capacity of the ash increased soil $\mathrm{pH}$, and this is also one of the reasons for reduced $\mathrm{CO}_{2}$ and $\mathrm{N}_{2} \mathrm{O}$ emissions. Soil $\mathrm{CO}_{2}$ and $\mathrm{N}_{2} \mathrm{O}$ emissions were not affected by soil temperature, but the emissions appear to be regulated by moderate soil temperature variation. The buffering capacity of pineapple residue ash decreases soil acidity; hence, this serves as a viable liming source for conventional agriculture production on tropical peat soils. The outcomes of this present study opine that converting pineapple residues as a useful source of soil amendment to minimize $\mathrm{CO}_{2}$ and $\mathrm{N}_{2} \mathrm{O}$ emissions offers a feasible option for managing pineapple wastes on peat soils without reducing peat soil and pineapple productivity. The findings from the study suggest that monthly fertilization using compound NPK fertilizers in combination with pineapple residue ash could be adopted by local farmers to improve agronomic efficiency by producing ash on a small scale in pineapple farms. Pineapple residue ash as a value-added product in pineapple cultivation will reduce farm operation costs, namely agricultural lime and fertilizer input and biomass burning for land preparation. These reductions will lower the risk of peat fires in the dry season and suppress $\mathrm{CO}_{2}$ and $\mathrm{N}_{2} \mathrm{O}$ emissions due to fertilization activities. However, further studies are required to enhance the formulation rate of pineapple residue ash in conjunction with compound NPK fertilizers, and ash production technique to improve its efficiency in improving nutrient adsorption and reducing $\mathrm{CO}_{2}$ and $\mathrm{N}_{2} \mathrm{O}$ emissions in cultivated tropical peat soils. These improvements include the optimization temperature for the thermochemical process and residence time in the combustion furnace. Results from one cycle of pineapple cultivation may not be sufficiently conclusive to verify the findings of the study. Thus, long-term soil greenhouse gas monitoring for pineapple cultivation at a larger scale is needed to confirm the results of this study, because factors such as soil microbiota, soil organic matter heterogeneity, and rainfall distribution may influence the outcome of the study. Additionally, the effect of pineapple residue ash on greenhouse gas emissions depends on the amount of ash added into the peat soil. It is crucial to determine the effect of ash with and without fertilizer application in the long-term because $\mathrm{CO}_{2}$ and $\mathrm{N}_{2} \mathrm{O}$ emissions is influenced by soil microbial activities. Next-generation sequencing (NGS) needs to be considered to assess the interaction between soil microbiota and the fate of pineapple residue ash in cultivated peat soils. This method may provide insights into the mechanism and microbially mediated processes that influence greenhouse gas emissions affected by ash addition. In addition, the characterization of gaseous compounds emitted during the combustion of plant residues in the furnace chamber during ash production needs to be determined. The characterization of gaseous by-products during the thermochemical process is needed to evaluate the environmental impact of pineapple residue ash as a value-added fertilizer product (life cycle assessment) and balance of soil $\mathrm{CO}_{2}$ and $\mathrm{N}_{2} \mathrm{O}$ emissions in pineapple cultivation on tropical peat soils. 
Author Contributions: Conceptualization, L.N.L.K.C.; methodology, L.N.L.K.C. and O.H.A.; validation, L.N.L.K.C. and O.H.A.; formal analysis, L.N.L.K.C. and O.H.A.; investigation, L.N.L.K.C. and O.H.A.; resources, L.N.L.K.C. and O.H.A.; data curation, L.N.L.K.C. and O.H.A.; writing-original draft preparation, L.N.L.K.C.; writing-review and editing, L.N.L.K.C., O.H.A., N.M.N.M., and Z.F.A.A.; visualization, L.N.L.K.C.; supervision, L.N.L.K.C. and O.H.A.; project administration, L.N.L.K.C.; funding acquisition, L.N.L.K.C. All authors have read and agreed to the published version of the manuscript.

Funding: This research was funded by the Ministry of Higher Education Malaysia through Fundamental Research Grant Scheme, grant number FRGS/1/2015/WAB01/MOA/02/2.

Institutional Review Board Statement: Not applicable.

Informed Consent Statement: Not applicable.

Data Availability Statement: Data is contained within the article.

Acknowledgments: The authors would like to extend their special thanks to Shamsiah Sekot (MARDI Saratok) for her assistance in the field sampling activities and plot maintenance throughout the study. The facilities provided by MARDI Saratok and Universiti Putra Malaysia Bintulu Campus for this study are appreciated.

Conflicts of Interest: The authors declare no conflict of interest.

\section{References}

1. Ahmed, O.H.; Ahmad Husni, M.H.; Rahim, A.A.; Mohd Hanafi, M. Sustainable Production of Pineapples on Tropical Peat Soils; Universiti Putra Malaysia Press: Serdang, Malaysia, 2013; pp. 1-141.

2. Hameed, B.H.; Krishni, R.R.; Sata, S.A. A novel agricultural waste adsorbent for the removal of cationic dye from aqueous solutions. J. Hazard. Mater. 2009, 162, 305-311. [CrossRef] [PubMed]

3. Lin, R.M.; Rahman, A.A. Status and impact of pineapple technology on mineral soil. Econ. Technol. Manag. Rev. 2010, 5, 11-19.

4. Marlier, M.E.; Liu, T.; Yu, K.; Buonocore, J.J.; Koplitz, S.N.; DeFries, R.S.; Mickley, L.J.; Jacob, D.J.; Schwartz, J.; Wardhana, B.S. Fires, smoke exposure, and public health: An integrative framework to maximize health benefits from peatland restoration. GeoHealth 2019, 3, 178-189. [CrossRef] [PubMed]

5. Page, S.E.; Hooijer, A. In the line of fire: The peatlands of Southeast Asia. Philos. Trans. R. Soc. B 2016, 371, 20150176. [CrossRef] [PubMed]

6. Uda, S.K.; Hein, L.; Atmoko, D. Assessing the health impacts of peatland fires: A case study for Central Kalimantan, Indonesia. Environ. Sci. Pollut. Res. 2019, 26, 31315-31327. [CrossRef] [PubMed]

7. Okazaki, M.; Watanabe, C.; Yoshikawa, M.; Yamaguchi, C.; Yoshimura, N. Chemical compounds in gas emitted from tropical peat soil burning: With and without oxygen. In Proceedings of the International Symposium of Tropical Peatlands, Bogor, Indonesia, 22-23 November 1999; pp. 27-32.

8. Ahmed, O.H.; Husni, M.H.A.; Syed Omar, R.S.; Hanafi, M.M.; Koh, S.K. The effect of residue management practices on phosphorus and potassium uptake in pineapple. Malays. J. Soil Sci. 1999, 3, 29-37.

9. Klemedtsson, L.; Ernfors, M.; Björk, R.G.; Weslien, P.; Rütting, T.; Crill, P. Reduction of greenhouse gas emissions by wood application to a Picea abis (L.) Karst. Forest on a drained organic soil. Eur. J. Soil Sci. 2010, 61, 734-744. [CrossRef]

10. Liimatainen, M.; Martikainen, P.J.; Maljanen, M. Why granulated wood ash decrease $\mathrm{N}_{2} \mathrm{O}$ production in boreal acidic peat soil? Soil Biol. Biochem. 2014, 79, 140-148. [CrossRef]

11. Couwenberg, J.; Hoojier, A. Towards robust subsidence-based soil carbon emission factors for peat soils in South-East Asia, with special reference to oil palm plantations. Mires Peat 2013, 12, 1-13. Available online: http:/ / www.mires-and-peat.net/pages / volumes/map12/map1201.php (accessed on 31 August 2014).

12. Melling, L.; Henson, I.E. Greenhouse gas exchange of tropical peatlands-A review. J. Oil Palm Res. 2011, 23, $1087-1095$.

13. Page, S.E.; Morrison, R.; Malins, C.; Hoojier, A.; Rieley, J.O.; Jauhiainen, J. Review of Peat Surface Greenhouse Gas Emissions from Oil Palm Plantations in Southeast Asia; (ICCT White Paper 15); International Council on Clean Transportation: Washington, DC, USA, 2011; pp. 40-45.

14. Choo, L.N.L.K.; Ahmed, O.H. Partitioning carbon dioxide emission and assessing dissolved organic carbon leaching of a drained peatland cultivated with pineapple at Saratok, Malaysia. Sci. World J. 2014, 906021. [CrossRef]

15. Choo, L.N.L.K.; Ahmed, O.H. Nitrous oxide emission of a tropical peat soil grown with pineapple at Saratok, Malaysia. Sustain. Agric. Res. 2017, 6, 75-84. [CrossRef]

16. Ahmed, O.H.; Choo, L.N.L.K. Greenhouse Gas Emission and Carbon Leaching in Pineapple Cultivation on Tropical Peat Soil; Universiti Putra Malaysia Press: Serdang, Malaysia, 2015; pp. 1-145.

17. Ahmed, O.H.; Jeffary, A.V.; Luta, W.; Choo, L.N.L.K. Tropical Peat Soil and Transportation of Greenhouse Gases; Universiti Putra Malaysia Press: Serdang, Malaysia, 2018; pp. 1-120. 
18. Jeffary, A.V.; Ahmed, O.H.; Heng, R.K.J.; Choo, L.N.L.K.; Omar, L. Horizontal and vertical emissions of carbon dioxide and methane from a tropical peat soil cultivated with pineapple (Ananas comosus (L.) Merr.). Sustain. Agric. Res. 2019, 8, 1-11. [CrossRef]

19. Luta, W.; Ahmed, O.H.; Heng, R.K.J.; Choo, L.N.L.K. Water table fluctuation and carbon dioxide emission from a tropical peat soil cultivated with pineapples (Ananas comosus L. Merr.). Int. J. Biosci. 2017, 10, 172-178. [CrossRef]

20. Kløve, B.; Sveistrup, T.E.; Hauge, A. Leaching of nutrients and emission of greenhouse gases from peatland cultivation at Bodin, Northern Norway. Geoderma 2010, 154, 219-232. [CrossRef]

21. Maljanen, M.; Komulainen, V.-M.; Hytönen, J.; Martikainen, P.J.; Laine, J. Carbon dioxide, nitrous oxide and methane dynamics in boreal organic agricultural soils with different soil characteristics. Soil Biol. Biochem. 2004, 36, 1801-1808. [CrossRef]

22. Kasimir-Klemedtsson, Å.; Klemedtsson, L.; Berglund, K.; Martikainen, P.; Silvola, J.; Oenema, O. Greenhouse gas emissions from farmed organic soils: A review. Soil Use Manag. 1997, 13, 245-250. [CrossRef]

23. Kuzyakov, Y. Sources of $\mathrm{CO}_{2}$ efflux from soil and review of partitioning methods. Soil Biol. Biochem. 2006, 38, 425-448. [CrossRef]

24. Veloo, R.; van Ranst, E.; Selliah, P. Peat characteristics and its impact on oil palm yield. NJAS Wagening. J. Life Sci. 2015, 72-73, 33-40. [CrossRef]

25. Jauhiainen, J.; Silvennoinen, H.; Hämäläinen, R.; Limin, S.; Raison, R.J.; Vasander, H. Nitrous oxide fluxes from tropical peat with different disturbance history and management. Biogeosciences 2012, 9, 1337-1350. [CrossRef]

26. Maljanen, M.; Martikkala, M.; Koponen, H.T.; Virkajärvi, P.; Martikainen, P.J. Fluxes of nitrous oxide and nitric oxide from experimental excreta patches in boreal agricultural soil. Soil Biol. Biochem. 2007, 39, 914-920. [CrossRef]

27. Hatala, J.A.; Detto, M.; Sonnentag, O.; Deverel, S.J.; Verfaille, J.; Baldocchi, D.D. Greenhouse gas $\left(\mathrm{CO}_{2}, \mathrm{CH}_{4}, \mathrm{H}_{2} \mathrm{O}\right)$ fluxes from drained and flooded agricultural peatlands in the Sacramento-San Joaquin Delta. Agr. Ecosyst. Environ. 2012, 150, 1-18. [CrossRef]

28. Kechavarzi, C.; Dawson, Q.; Bartlett, M.; Leeds-Harrison, P.B. The role of soil moisture, temperature and nutrient amendment on $\mathrm{CO}_{2}$ efflux from agricultural peat soil microcosms. Geoderma 2010, 154, 203-210. [CrossRef]

29. Jauhiainen, J.; Kerojoki, O.; Silvennoinen, H.; Limin, S.; Vasander, H. Heterotrophic respiration in drained tropical peat is greatly affected by temperature-A passive ecosystem cooling experiment. Environ. Res. Lett. 2014, 9, 105013. [CrossRef]

30. Mäkiranta, P.; Minkkinen, K.; Hytönen, J.; Laine, J. Factors causing temporal and spatial variation in heterotrophic and rhizospheric components of soil respiration in afforested organic soil croplands in Finland. Soil Biol. Biochem. 2008, 40, 1592-1600. [CrossRef]

31. Murayama, S.; Bakar, Z.A. Decomposition of tropical peat soils 2. Estimation of in situ decomposition by measurement of $\mathrm{CO}_{2}$ flux. Jpn. Agric. Res. Q. 1996, 30, 153-158.

32. Oktarita, S.; Hergoualc'h, K.; Anwar, S.; Verchot, V. Substantial $\mathrm{N}_{2} \mathrm{O}$ emissions from peat decomposition and $\mathrm{N}$ fertilization in an oil palm plantation exacerbated by hotspots. Environ. Res. Lett. 2017, 12, 104007. [CrossRef]

33. Van Beek, C.L.; Pleijter, M.; Kuikman, P.J. Nitrous oxide emissions from fertilized and unfertilized grasslands on peat soil. Nutr. Cycl. Agroecosys. 2011, 89, 453-461. [CrossRef]

34. Mohammed Selamat, M.; Abdul Rahman, H. Amalan kultur. In Penanaman Nanas-Nanas Makan Segar dan Nanas Kaleng; Mohammed Selamat, M., Ed.; MARDI: Serdang, Malaysia, 1996; pp. 22-34.

35. Rastogi, M.; Singh, S.; Pathak, H. Emission of carbon dioxide from soil. Curr. Sci. 2002, 82, 510-517.

36. Aerts, R.; Toet, S. Nutritional controls on carbon dioxide and methane emission from carex-dominated peat soils. Soil Biol. Biochem. 1997, 29, 1683-1690. [CrossRef]

37. Zimmerman, A.R.; Gao, B.; Ahn, M.Y. Positive and negative carbon mineralization priming effects among a variety of biocharamended soils. Soil Biol. Biochem. 2011, 43, 1169-1179. [CrossRef]

38. Kuzyakov, Y. Priming effects: Interactions between living and dead organic matter. Soil Biol. Biochem. 2010, $42,1363-1371$. [CrossRef]

39. Chen, J.; Kim, H.; Yoo, G. Effects of biochar addition on $\mathrm{CO}_{2}$ and $\mathrm{N}_{2} \mathrm{O}$ emissions following fertilizer application to a cultivated grassland soil. PLoS ONE 2015, 10, e1026841. [CrossRef] [PubMed]

40. Butnan, S.; Deenik, J.L.; Toomsan, B.; Antal, M.J.; Vityakon, P. Biochar properties influencing greenhouse gas emissions in tropical soils differing in texture and mineralogy. J. Environ. Qual. 2016, 45, 1509-1519. [CrossRef] [PubMed]

41. NRE. Malaysia Biennial Update Report to the UNFCCC; Ministry of Natural Resources and Environment Malaysia: Putrajaya, Malaysia, 2015; pp. 31-44.

42. Murdiyarso, D.; Hergoualc'h, K.; Verchot, L.V. Opportunities for reducing greenhouse gas emissions in tropical peatlands. Proc. Natl. Acad. Sci. USA 2010, 107, 19655-19660. [CrossRef] [PubMed]

43. Reukeith, G.O. State to up Production of MD2 Variety Pineapples-Jabu. Available online: https://www.theborneopost.com/2015 /12/01/state-to-up-production-of-md2-variety-pineapples-jabu/ (accessed on 30 November 2015).

44. James, A.K.; Thring, R.W.; Helle, S.; Ghuman, H.S. Ash management reviews—applications of biomass bottom ash. Energies 2012, 5, 3856-3873. [CrossRef]

45. Quirantes, M.; Calvo, F.; Romero, E.; Nogales, R. Soil nutrient availability affected by different biomass-ash applications. J. Soil Sci. Plant Nutr. 2016, 16, 159-163. [CrossRef]

46. Salvo, M.; Rizzo, S.; Caldirola, M.; Novajra, G.; Canonico, F.; Bianchi, M.; Ferraris, M. Biomass ash as supplementary cementitious material (SCM). Adv. Appl. Ceram. 2015, 114, S3-S10. [CrossRef] 
47. Kalus, K.; Koziel, J.A.; Opaliński, S. A review of biochar properties and their utilization in crop agriculture and livestock production. Appl. Sci. 2019, 9, 3494. [CrossRef]

48. Rawat, J.; Saxena, J.; Sanwal, P. Biochar: A sustainable approach for improving plant growth and soil properties. In Biochar-An Imperative Amendment for Soil and the Environment; Abrol, V., Sharma, P., Eds.; IntechOpen: London, UK, 2019; pp. 1-17. [CrossRef]

49. Saletnik, B.; Zagula, G.; Bajcar, M.; Czernicka, M.; Puchalski, C. Biochar and biomass ash as a soil ameliorant: The effect on selected soil properties and yield of giant Miscanthus (Mischanthus x giganteus). Energies 2018, 11, 2535. [CrossRef]

50. Tan, R.R. Data challenges in optimizing biochar-based carbon sequestration. Renew. Sustain. Energy Rev. 2019, 174-177. [CrossRef]

51. Zając, G.; Szyszlak-Bargłowicz, J.; Gołebiowski, W.; Szczepanik, M. Chemical characteristics of biomass ashes. Energies 2018, 11, 2885. [CrossRef]

52. Masebinu, S.O.; Akinlabi, E.T.; Muzenda, E.; Aboyade, A.O. A review of biochar properties and their roles in mitigating challenges with anaerobic digestion. Renew. Sustain. Energy Rev. 2019, 103, 291-307. [CrossRef]

53. Tomczzyk, A.; Sokołowska, Z.; Boguta, P. Biochar physicochemical properties: Pyrolysis temperature and feedstock kind effects. Rev. Environ. Sci. Biotechnol. 2020, 19, 191-215. [CrossRef]

54. Weber, K.; Quicker, P. Properties of biochar. Fuel 2018, 217, 240-261. [CrossRef]

55. Jaji, K.; Man, N.; Nawi, N.M. Factors affecting pineapple market supply in Johor, Malaysia. Int. Food Res. J. 2018, 25, 366-375.

56. DOA. Crop Statistics Booklet (Food Crop Sub-Sector); Department of Agriculture Malaysia: Putrajaya, Malaysia, 2018 ; p. 49.

57. Othman, A.F. Pineapples New Source of Wealth for Malaysia. Available online: https://www.nst.com.my/news/nation/2017/1 2/313347 / pineapples-new-source-wealth-malaysia (accessed on 11 December 2017).

58. Ahmed, O.H.; Husni, A.M.H.; Anuar, R.A.; Hanafi, M.M. Alternative means of recycling pineapple leaf residues. Fruits 2003, 58, 53-60. [CrossRef]

59. Daud, Z.; Hatta, M.Z.M.; Kassim, A.S.M.; Aripin, A.M. Suitability of Malaysia's pineapple leaf and napier grass as fibre substitution for paper making industry. In Proceedings of the 6th Engineering Conference-Energy and Environment, Kuching, Malaysia, 2-4 July 2013; p. 4.

60. Liu, C.H.; Liu, Y.; Fan, C.; Kuang, S.Z. The effects of composted pineapple residue return on soil properties and the growth and yield of pineapple. J. Soil Sci. Plant Nutr. 2013, 433-444. [CrossRef]

61. dos Santos, R.M.; Neto, W.P.F.; Silvério, H.A.; Martins, D.F.; Dantas, N.O.; Pasquini, D. Cellulose nanocrystals from pineapple leaf, a new approach for the reuse of this agro-waste. Ind. Crops Prod. 2013, 50, 707-714. [CrossRef]

62. Yahya, M.A.; Al-Qodah, Z.; Ngah, C.W.Z. Agricultural bio-waste materials as potential sustainable precursors used for activated carbon production: A review. Renew. Sustain. Energy Rev. 2015, 46, 218-235. [CrossRef]

63. Lim, E.T. Peat Soils of Sarawak and the Analytical Methods; Department of Agriculture Sarawak: Kuching, Malaysia, 1991; pp. 25-28.

64. Ismail, A.B.; Asing, J.; Zulkefli, M. Residual impact of various land clearing techniques on peat chemical characteristics. In $A$ Case Study at MARDI Peat Research Station, Sessang, Sarawak, Malaysia; Ismail, A.B., Ong, H.K., Mohamad Hanif, M.J., Umi Kalsom, M.S., Eds.; MARDI: Serdang, Malaysia, 2007; pp. 33-61.

65. Harada, Y.; Inoko, A. The measurement of the cation exchange capacity of composts for the estimation of the degree of maturity. Soil Sci. Plant Nutr. 1980, 26, 127-134. [CrossRef]

66. Nelson, D.W.; Sommers, L.E. Total carbon, organic carbon and organic matter. In Methods of Soil Analysis, Part 2. Chemical and Microbiological Properties, 2nd ed.; Page, A.L., Baker, D.E., Ellis, R., Jr., Keeney, D.R., Miller, R.H., Rhoades, J.D., Eds.; ASA-SSSA Madison, WI, USA, 1982; pp. 539-579.

67. Bremner, J.M.; Mulvaney, C.S. Nitrogen-total. In Methods of Soil Analysis, Part 2. Chemical and Microbiological Properties, 2nd ed.; Page, A.L., Baker, D.E., Ellis, R., Jr., Keeney, D.R., Miller, R.H., Rhoades, J.D., Eds.; ASA-SSSA: Madison, WI, USA, 1982; pp. 595-624.

68. Bremner, J.M.; Keeney, D.R. Determination and isotope-ratio analysis of different forms of nitrogen in soils: 3. Exchangeable ammonium, nitrate and nitrite by extraction-distillation methods. Soil Sci. Soc. Am. J. 1966, 30, 577-582. [CrossRef]

69. Leng, L.Y.; Husni, M.H.; Samsuri, A.W. Comparison of the carbon-sequestering abilities of pineapple leaf residue chars produced by controlled combustion and by field burning. Bioresour. Technol. 2011, 102, 10759-10762. [CrossRef] [PubMed]

70. Wiersum, L.K.; Bakema, K. Competitive adaptation of the cation exchange capacity of roots. Plant Soil 1959, 11, 287-292. [CrossRef]

71. Abbas, H.; Mahmood, Z.; Maamun, T.M.T.; Ghazali, M.S. Formulation for pineapple in Malaysia. MARDI Tech. Bull. 2015, 8, 7-15.

72. Choo, L.N.L.K.; Ahmed, O.H.; Nik Majid, N.M.; Ab Aziz, Z.F. Improving nitrogen availability on a tropical peat soil cultivated with Ananas comosus L. Merr. using pineapple residue ash. J. Soil Sci. Plant Nutr. 2020, 20, 657-672. [CrossRef]

73. Lehmann, J.; Kaiser, K.; Peter, I. Exchange resin cores for the estimation of nutrient fluxes in highly permeable tropical soil. J. Plant Nutr. Soil Sci. 2001, 164, 57-64. [CrossRef]

74. IAEA. Methane and nitrous oxide flux measurements form soil and plant systems. In Manual on Measurement of Methane and Nitrous Oxide Emissions from Agriculture; IAEA-TECDOC-674; IAEA: Vienna, Austria, 1992; pp. 45-79.

75. Widén, B.; Lindroth, A. A calibration system for soil carbon dioxide-efflux measurement chambers. Soil Sci. Soc. Am. J. 2003, 67, 327-334. [CrossRef]

76. Sim, A.K.F.; Ishak, C.F.; Hanif, A.H.M.; Melling, L. Effect of $\mathrm{N}$ fertilization on $\mathrm{N}_{2} \mathrm{O}$ emission from a tropical peat soil: A laboratory incubation study. In Proceedings of the 14th International Peat Congress: Peatlands in Balance, Stockholm, Sweden, 3-8 June 2012; p. 7. 
77. Andriesse, J.P. Nature and Management of Tropical Peat Soils; FAO Soils Bulletin 59; FAO: Rome, Italy, 1988.

78. Funakawa, S.; Yonebayashi, K.; Shoon, J.F.; Khun, E.C.O. Nutritional environment of tropical peat soils in Sarawak, Malaysia based on soil solution composition. Soil Sci. Plant Nutr. 1996, 42, 833-843. [CrossRef]

79. Hashim, S.A.; Teh, C.B.S.; Ahmed, O.H. Influence of water table depths, nutrient leaching losses, subsidence of tropical peat soil and oil palm (Elaeis guineensis Jacq.) seedling growth. Malays. J. Soil Sci. 2019, 23, 13-30.

80. Huat, B.B.K.; Kazemian, S.; Prasad, A.; Barghchi, M. State of an art review of peat: General perspective. Int. J. Phys. Sci. 2011, 6, 1988-1996.

81. Könönen, M.; Jauhiainen, J.; Laiho, R.; Kusin, K.; Vasander, H. Physical and chemical properties of tropical peat under stabilized land uses. Mires Peat 2015, 16, 8. Available online: http://www.mires-and-peat.net/pages/volumes/map16/map1608.php (accessed on 16 September 2016).

82. MARDI. Master Plan for Malaysian Agricultural Research and Development Institute Sessang Peat Research Station; MARDI: Serdang, Malaysia, 1996; pp. 16-22.

83. Murtedza, M.; Padmanabhan, E.; Mei, B.L.H.; Siong, W.B. The Peat Soils of Sarawak, STRAPEAT Status Report; UNIMAS: Sarawak, Malaysia, 2002; pp. 1-16.

84. Othman, H.; Darus, F.M.; Mohammed, A.T. Experiences in peat development for oil palm planting in the MPOB Research Station at Sessang, Saratok. Oil Palm Bull. 2009, 58, 1-13.

85. Reeza, A.A.; Hussin, A.; Hanif, A.H.M.; Sukari, M.A.M. Effect of liming and fertilizer application in hemic and sapric of tropical peat: Phosphorus mineralization, infra-red spectroscopy and microscopy. Am. J. Agric. Biol. Sci. 2014, 9, 321-333. [CrossRef]

86. Mutalib, A.A.; Lim, J.S.; Wong, M.H.; Koonvai, L. Characterization, distribution, and utilization of peat in Malaysia. In Proceedings of the International Symposium on Tropical Peatland, Kuching, Malaysia, 6-10 May 1991; pp. 7-16.

87. Ahmad, M.; Rajapaksha, A.U.; Lim, J.E.; Zhang, M.; Bolan, N.; Mohan, D.; Vithanage, M.; Lee, S.S.; Ok, Y.S. Biochar as a sorbent for contaminant management in soil and water: A review. Chemosphere 2014, 99, 19-33. [CrossRef]

88. Czimczik, C.I.; Masiello, C.A. Controls on black carbon storage in soils. Glob. Biogeochem. Cycles 2007, 21, GB3005. [CrossRef]

89. Yangyuoru, M.; Boateng, E.; Adiku, S.G.K.; Acquah, D.; Adjadeh, T.A.; Mawunya, F. Effects of natural and synthetic soil conditioners on soil moisture rentention and maize yield. West Afr. J. Appl. Ecol. 2006, 9, 1-8. [CrossRef]

90. Kasozi, G.N.; Zimmerman, A.R.; Nkedi-Kizza, P.; Gao, B. Catechol and humic acid sorption onto a range of laboratory-produced black carbons (biochars). Environ. Sci. Technol. 2010, 44, 6189-6195. [CrossRef]

91. Kuzyakov, Y.; Friedel, J.K.; Stahr, K. Review of mechanisms and quantification of priming effects. Soil Biol. Biochem. 2000, 32, 1485-1498. [CrossRef]

92. Moradshashi, A.; Vines, H.M.; Black, C.C. $\mathrm{CO}_{2}$ exchange and acidity levels in pineapple, Ananas comosus (L.), Merr., leaves during the day at various temperature, $\mathrm{O}_{2}$ and $\mathrm{CO}_{2}$ concentrations. Plant Physiol. 1977, 59, 274-278. [CrossRef]

93. Ritchie, R.J.; Bunthawin, S. Photosynthesis in pineapple (Ananas comosus comosus [L.] Merr) measured using PAM (Pulse Amplitude Modulation) Fluorometry. Trop. Plant Biol. 2010, 3, 193-203. [CrossRef]

94. Mohammed Selamat, M. Biologi tanaman dan keperluan persekitaran. In Penanaman Nanas—Nanas Makan Segar dan Nanas Kaleng; Mohammed Selamat, M., Ed.; MARDI: Serdang, Malaysia, 1996; pp. 7-16.

95. Yamori, W.; Hikosaka, K.; Way, D.A. Temperature response of photosynthesis in $\mathrm{C}_{3}, \mathrm{C}_{4}$, and CAM plants: Temperature acclimation and temperature adaptation. Photosynth. Res. 2014, 119, 101-117. [CrossRef] [PubMed]

96. Saggar, S.; Jha, N.; Deslippe, J.; Bolan, N.S.; Luo, J.; Giltrap, D.L.; Kim, D.G.; Zaman, M.; Tillman, R.W. Denitrification and N2 O:N 2 production in temperate grasslands: Processes, measurements, modeling and mitigating negative impacts. Sci. Total Environ. 2013, 465, 173-195. [CrossRef] [PubMed]

97. Perrin, T.S.; Boettinger, J.L.; Drost, D.T.; Norton, J.M. Decreasing nitrogen leaching from sandy soil with ammonium-loaded clinoptilolite zeolite. J. Environ. Qual. 1998, 27, 656-663. [CrossRef]

98. Mäkiranta, P.; Laiho, R.; Fritze, H.; Hytönen, J.; Laine, J.; Minkkinen, K. Indirect regulation of heterotrophic peat soil respiration by water level via microbial community structure and temperature sensitity. Soil Biol. Biochem. 2009, 41, 695-703. [CrossRef]

99. Chan, S.L.; Tan, Y.P.; Abdullah, A.H.; Ong, S.T. Equilibrium, kinetic and thermodynamic studies of a new potential biosorbent for the removal of basic blue 3 and congo red eyes: Pineapple (Ananas comosus) plant stem. J. Taiwan Inst. Chem. 2016, 61, 306-315. [CrossRef]

100. Mahamad, M.N.; Ahmad Zaini, M.A.; Zakaria, Z.A. Preparation and characterization of activated carbon from pineapple waste biomass for dye removal. Int. Biodeter. Biodegr. 2015, 102, 274-280. [CrossRef]

101. Luey, J.K.; Darab, J.G.; Autrey, T.S.; Vienna, J.D.; Wigent, H.L. Characterization of Offgas Generated during Calcination of Incinerator Ash Surrogates; PNNL-11982-UC-2000; Pacific Northwest National Laboratory: Washington, DC, USA, $1999 ;$ pp. $22-34$.

102. Pardo, M.E.S.; Cassellis, M.E.R.; Escobedo, R.M.; Garcia, E.J. Chemical characterization of the industrial residues of the pineapple (Ananas comosus). J. Agric. Chem. Environ. 2014, 3, 53-56. [CrossRef]

103. Berglund, Ö.; Berglund, K. Influence of water table level and soil properties on emissions of greenhouse gases from cultivated peat soil. Soil Biol. Biochem. 2011, 43, 923-931. [CrossRef] 